\title{
Relative Sea-Level Rise Scenario for 2100 along the Coast of South Eastern Sicily (Italy) by InSAR Data, Satellite Images and High-Resolution Topography
}

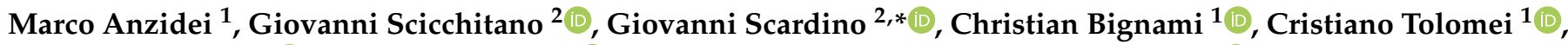

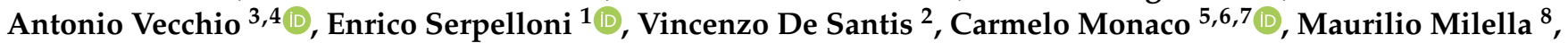 \\ Arcangelo Piscitelli ${ }^{8}$ and Giuseppe Mastronuzzi ${ }^{2}$
}

Citation: Anzidei, M.; Scicchitano, G.; Scardino, G.; Bignami, C.; Tolomei, C.; Vecchio, A.; Serpelloni, E.; De Santis, V.; Monaco, C.; Milella, M.; et al. Relative Sea-Level Rise Scenario for 2100 along the Coast of South Eastern Sicily (Italy) by InSAR Data, Satellite Images and High-Resolution Topography. Remote Sens. 2021, 13, 1108. https://doi.org/10.3390/ rs13061108

Academic Editor: Xiaoli Deng

Received: 25 January 2021

Accepted: 11 March 2021

Published: 15 March 2021

Publisher's Note: MDPI stays neutral with regard to jurisdictional claims in published maps and institutional affiliations.

Copyright: (c) 2021 by the authors. Licensee MDPI, Basel, Switzerland. This article is an open access article distributed under the terms and conditions of the Creative Commons Attribution (CC BY) license (https:// creativecommons.org/licenses/by/ $4.0 /)$.
1 Istituto Nazionale di Geofisica e Vulcanologia, 00143 Roma, Italy; marco.anzidei@ingv.it (M.A.); christian.bignami@ingv.it (C.B.); cristiano.tolomei@ingv.it (C.T.); enrico.serpelloni@ingv.it (E.S.)

2 Dipartimento di Scienze della Terra e Geoambientali, Università degli Studi di Bari Aldo Moro, 70121 Bari, Italy; giovanni.scicchitano@uniba.it (G.S.); vincenzo.desantis@uniba.it (V.D.S.); giuseppe.mastronuzzi@uniba.it (G.M.)

3 Radboud Radio Lab, Department of Astrophysics/IMAPP-Radboud University, P.O. Box 9010, 6500 GL Nijmegen, The Netherlands; a.vecchio@astro.ru.nl

4 LESIA, Observatoire de Paris, Université PSL, CNRS, Sorbonne Université, Univ. Paris Diderot, Sorbonne Paris Cité, 5 Place Jules Janssen, 92195 Meudon, France

5 Dipartimento di Scienze Biologiche, Geologiche e Ambientali, Università degli Studi di Catania, 95129 Catania, Italy; cmonaco@unict.it

6 CRUST-Interuniversity Center for 3D Seismotectonics with Territorial Applications, 66100 Chieti, Italy

7 Istituto Nazionale di Geofisica e Vulcanologia, Osservatorio Etneo, 95125 Catania, Italy

8 Environmental Surveys S.r.l., Spin-Off Università degli Studi di Bari Aldo Moro, 74121 Taranto, Italy; mauriliomilella@ensu.it (M.M.); arcangelopiscitelli@ensu.it (A.P.)

* Correspondence: giovanni.scardino@uniba.it

\begin{abstract}
The global sea-level rise (SLR) projections for the next few decades are the basis for developing flooding maps that depict the expected hazard scenarios. However, the spatially variable land subsidence has generally not been considered in the current projections. In this study, we use geodetic data from global navigation satellite system (GNSS), synthetic aperture radar interferometric measurements (InSAR) and sea-level data from tidal stations to show the combined effects of land subsidence and SLR along the coast between Catania and Marzamemi, in south-eastern Sicily (southern Italy). This is one of the most active tectonic areas of the Mediterranean basin, which drives accelerated SLR, continuous coastal retreat and increasing effects of flooding and storms surges. We focus on six selected areas, which show valuable coastal infrastructures and natural reserves where the expected SLR in the next few years could be a potential cause of significant land flooding and morphological changes of the coastal strip. Through a multidisciplinary study, the multi-temporal flooding scenarios until 2100, have been estimated. Results are based on the spatially variable rates of vertical land movements (VLM), the topographic features of the area provided by airborne Light Detection And Ranging (LiDAR) data and the Intergovernmental Panel on Climate Change (IPCC) projections of SLR in the Representative Concentration Pathways RCP 2.6 and RCP 8.5 emission scenarios. In addition, from the analysis of the time series of optical satellite images, a coastal retreat up to $70 \mathrm{~m}$ has been observed at the Ciane river mouth (Siracusa) in the time span 2001-2019. Our results show a diffuse land subsidence locally exceeding $10 \pm 2.5 \mathrm{~mm}$ /year in some areas, due to compacting artificial landfill, salt marshes and Holocene soft deposits. Given ongoing land subsidence, a high end of RSLR in the RCP 8.5 at $0.52 \pm 0.05 \mathrm{~m}$ and $1.52 \pm 0.13 \mathrm{~m}$ is expected for $2050 \mathrm{AD}$ and $2100 \mathrm{AD}$, respectively, with an exposed area of about $9.7 \mathrm{~km}^{2}$ that will be vulnerable to inundation in the next 80 years.
\end{abstract}

Keywords: Sicily; sea-level rise; subsidence; flooding scenario 2100 A.D.; InSAR; GNSS; LiDAR 


\section{Introduction}

Sea-level rise (SLR) is one of the major consequences of global warming, driving the melting of ice sheets and the thermal expansion of the oceans, increasing the vulnerability of coastal areas to flooding. Over the past two centuries, the global sea-level (GSL) has risen at faster rates than in the last two millennia [1,2], with values from $1.7 \mathrm{~mm} /$ year in the late 20th century up to $3.2 \mathrm{~mm}$ /year over the last decades [3-6]. The latest report of Intergovernmental Panel on Climate Change (IPCC, Special Report on the Ocean and Cryosphere in a Changing Climate SROCC [7]) shows that in 2100, GSL projection has an upper limit of about $1.1 \mathrm{~m}$ higher than present sea-level, while about 400 million of people will be highly exposed to coastal hazard. SLR can be exacerbated by land subsidence from natural (i.e., tectonic and volcanic activity and sediment compaction) and anthropogenic causes (i.e., fluid withdrawal, dams building), accelerating the submersion process of low-elevated continental [8-10] and insular coasts [11-13]. Coastal flooding is likely to be the biggest socioeconomic impact of SLR in the 21st century [14] exceeding the damage caused by earthquakes and volcanic eruptions.

Recently, Toimil et al. [15] delineated the requirements for a scientific approach for future projections of shoreline changes, which should consider changes in the mean sealevel, storm surges, coastal erosion and other additional factors, with the aim of reducing uncertainty in coastal change estimates. Indeed, the rate of relative SLR (RSLR) can vary significantly due to other processes such as isostatic adjustments, ocean currents, seismic and volcanic activity, besides the already cited natural and anthropogenic land subsidence. These phenomena are already affecting the global coasts and large coastal cities [16], including the Mediterranean [17] (www.savemedcoasts.eu and www.savemedcoasts2.eu, accessed on 4 February 2021 [18]). SLR, in conjunction with extreme storm surge events, caused dramatic flooding, such as in 1953 for the coast of Netherlands or more recently in New Jersey (2012, Hurricane Sandy), Louisiana (2015, Hurricane Katrina), Florida (2016, Hurricane Matthew), Louisiana and Texas (2017, Hurricane Harvey) and in the Mediterranean Sea in 2019 and 2020 [19-21].

Because relative sea-level change along the coast is given by the sum of eustatic, thermo-steric, isostatic, sediment compaction and tectonic factors [22,23], the projection of the future coastline positions in specific zones require to consider in the analysis: (i) the local rate and trend of sea-level change and (ii) the rate of vertical land movements (VLM), including tectonic and isostatic contributions and anthropogenic influence. The first are provided by the latest IPCC reports $[7,24]$ and can be downscaled for specific regions, while the second are provided by geodetic data, such as sparsely GNSS stations and InSAR observations [25]. The latter can much improve the spatial coverage and resolution to characterize and detail land subsidence, whereas GNSS provide precise measurements in well-defined, ground-based, reference frame, to which InSAR measurements can be referred. Assuming that VLM rates estimated from geodetic data will remain constant for the next few decades in a specific coastal zone, i.e., in absence of any relevant tectonic event, relative sea-level rise projections and flooding scenarios for the coming years (2100) can be reasonably realized. Scenarios can be mapped on high resolution 3D topography of the investigated zones, supporting the analysis of the flooding extension and the assessment of the coastal impacts. Digital Elevation Models (DEM) extracted by LiDAR data are the most suitable tools to realize realistic scenarios.

Here, we report on accurate observations of VLM along the coast of southern Sicily between the city of Catania and the village of Marzamemi, from a combination of GNSS, InSAR and tide gauge observations at an unprecedented resolution and accuracy (Figures 1 and 2). This allowed us to provide the first multitemporal RSLR projections up to 2100 for this area, providing high resolution inundation maps based on the IPCC projections downscaled for the Mediterranean Sea. Projections of revised SLR for the central Mediterranean provided by the IPCC 2019 (SROCC report, Oppenheimer et al. [7,26]) predict a rise of $0.15 \pm 0.04$ to $0.20 \pm 0.05 \mathrm{~m}$ by 2050 and $0.33 \pm 0.07$ to $0.72 \pm 0.13 \mathrm{~m}$ by 2100, relative to 2016, based on different RCPs of greenhouse-gas emission scenarios. 

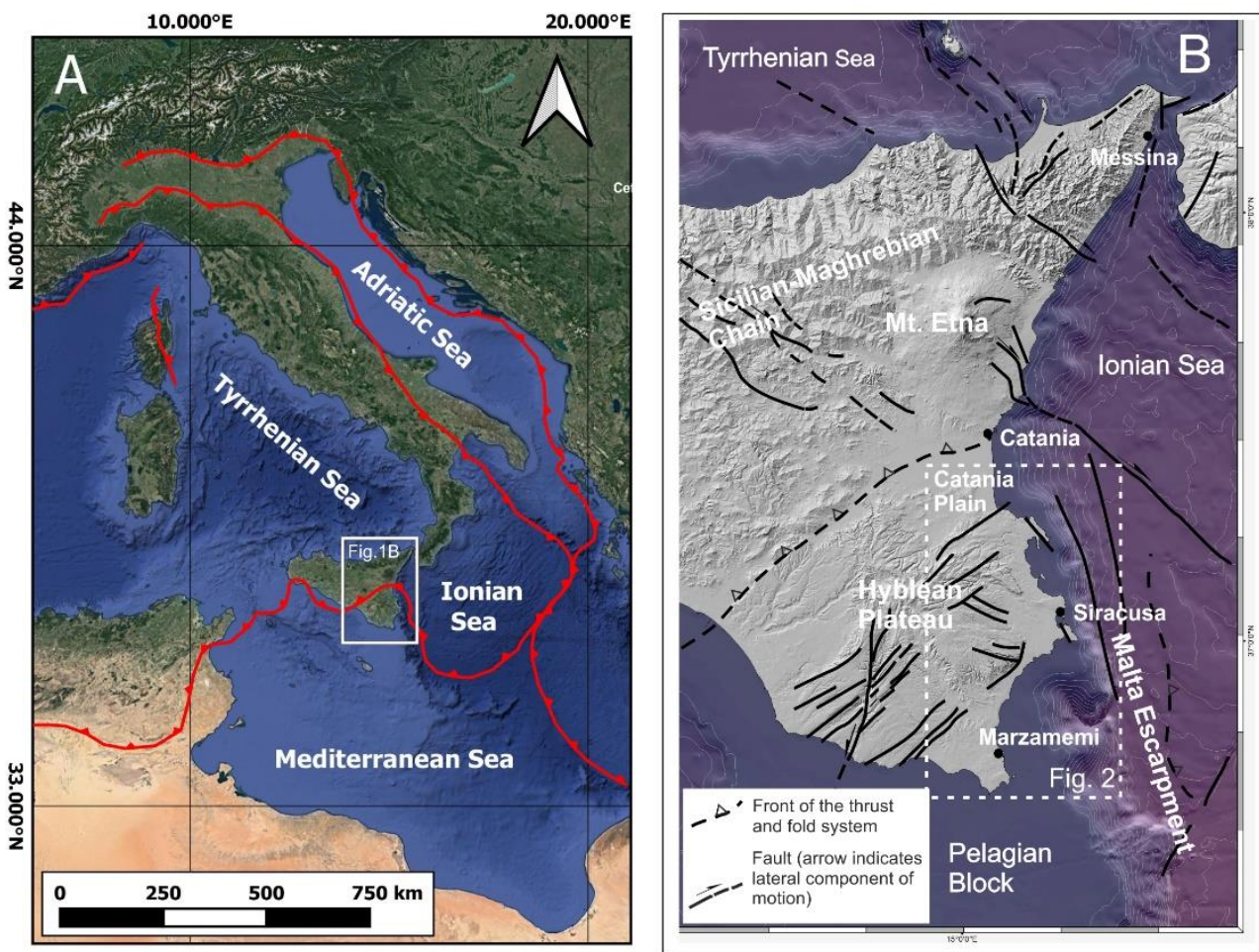

Figure 1. Tectonic and kinematic sketch of the Sicily-Calabria region. (A) The white rectangle is the investigated area in this study (basemap by Google Satellite). The thick red lines show seismic belts not clearly associated with well constrained fault systems. (B) Instrumental seismicity [27] and the Italian Seismic Instrumental and parametric Database have been considered (ISIDE; available at http:/ / iside.rm.ingv.it (accessed on 6 January 2021) [28]).

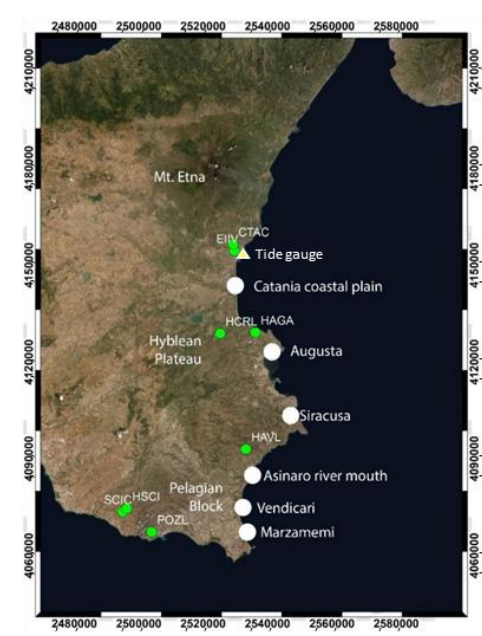

(a)

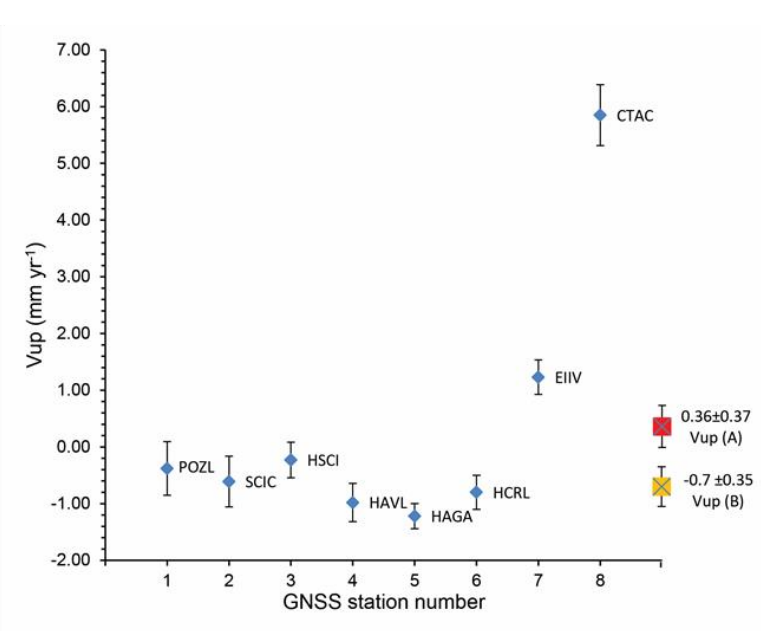

(b)

Figure 2. Study area of south-eastern Sicily (basemap by Google Satellite); (a) Location of the six investigated sites along the coast of southern Sicily (white dots) and position of the GNSS stations (green dots). (b) Vertical land velocities (Vup, mm/year) estimated at the GNSS stations located between Catania and Capo Passero within $10 \mathrm{~km}$ of the coast. The red and orange squares show the mean Vup values: Vup (A) includes the GNSS stations located at the foot of the Etna Volcano which recorded the uplift linked with the latest eruption activity; Vup (B) is the mean velocity excluding CTAC and EIIV which are located close to Etna. 3. The vertical velocities fit the GIA values for this region which have been estimated between -0.5 and $-1 \mathrm{~mm} /$ year [29]. 
IPCC projections have already been used to identify areas of potential inundation in coastal regions of the Mediterranean [11,17,18,30-32] and especially in USA for planning flood resilience strategies for large coastal urban areas such as in San Francisco, the Los Angeles Basin and New York [16,33,34].

In this study, we focus on six selected areas characterized by low elevated topography, relevant coastal infrastructures and natural areas, where the expected SLR could be a potential cause of large inland flooding and morphological changes of the coastal stretches (Figure 2).

To reconstruct the retreating coasts in the recent past, optical images from satellites over the last two decades have been analysed in conjunction with tide gauge data and current rates of VLM estimated in this study. An integration between RSLR and effective horizontal shoreline migration allowed to map the future submersion surfaces on highresolution Digital Elevation Models, thus to predict the submersion scenarios up to 2050 and 2100.

\section{South-Eastern Sicily: Geodynamic and Geological Setting}

South-eastern Sicily, between the Catania Plain in the north and Capo Passero in the south, is shaped by compressional, extensional and strike slip movements related to the relative motion of the Africa and Eurasia tectonic plates, where geodynamic processes associated with subduction of the Ionian lithosphere beneath the Calabrian arc cause a complex volcano-tectonics [35,36] (Figure 1). The geology of this region shows thick Mesozoic to Quaternary carbonate sedimentary sequences and volcanic layers forming the emerged foreland of the Sicilian-Maghrebian thrust belt [37]. The most important tectonic domains of this area are the Hyblean Plateau and the Malta escarpment. The latter is a Mesozoic boundary separating the continental domain from the oceanic crust of the Ionian basin, reactivated during the Quaternary [38-40].

Since the Early-Middle Pleistocene, active faulting has contributed to extensional deformation along the coastal sector of south-eastern Sicily, where NNW-SSE trending normal faults control the Ionian shoreline [40-42]. These structures are mostly located offshore and their Quaternary activity is probably associated with the recent reactivation of the Malta Escarpment system [43]. This area is marked by a high level of crustal seismicity that released earthquakes of a magnitude of about 7 , such as the destructive events occurred in 1169, 1542 and 1693 [44,45]. The seismogenic sources of these historical events is still debated but they are likely located in the Malta Escarpment, between Catania and Siracusa [36,40,42-44,46-49]. The last major earthquake (ML 5.4) occurred on December 13, 1990 in the Augusta off-shore [50-52].

Due to geodynamic processes, such as the retreating of the subducted Ionian slab [53-55] or asthenospheric flow beneath a decoupled crust [56,57], and off-shore normal faulting [43,58], during the Late Quaternary, this area has been affected by regional uplifting. Uplift progressively decreases north of southern Calabria and south of north-eastern Sicily, as shown by flights of marine terraces developed along the coasts [53,59-61]. In the northern sector of south-eastern Sicily, the long-term uplift has been estimated at rates of $0.2-0.7 \mathrm{~mm} /$ year from Middle-Upper Quaternary marine terraces and paleo-shorelines $[40,58,62,63]$, gradually decreasing to zero toward the stable areas of the south-eastern corner of Sicily $[59,64]$.

Toward the south-eastern corner of Sicily, the observed uplift also decreases during the Holocene. In fact, archaeological and borehole evidence show vertical land stability or weak uplift during the late Holocene [65-68].

On the other hand, levelling surveys performed since 1970 [61,69] and more recent GNSS data [29,70,71] and InSAR analysis [72], highlighted a diffuse and interseismic low rate land subsidence between Catania and Siracusa, which is in contrast with the long term geological uplift of this region.

The studied coastal area has been affected by several marine extreme events in historical times. Effects of several tsunamis have been reconstructed from the analyses of boulder accumulation [73], high-energy deposits [74] and cores performed inside la- 
goons $[75,76]$. The analysed area also experienced the effects of several storms and Medicanes occurred over the last decades, mainly represented by boulders dislocation along the coastal area [19]. This is particularly important considering that in a SLR scenario the effects of the extreme marine events will probably impact on the coastal landscapes currently emerged [31,32,68,77-80].

\section{Material and Methods}

To realize high resolution maps of expected coastal flooding by 2100, we have analyzed the following data sets: (i) geodetic data from GNSS networks and InSAR observations to estimate the current rates of VLM for the last two decades; (ii) time series of sea-level data collected in the time span 1992-2020 at the tide gauge station of Catania; (iii) optical satellite images to evaluate the intervening coastal retreat occurred in the time span 20012019; (iv) sea-level projection released by the IPCC (Report SROCC [7]) corrected for the Mediterranean Sea to obtain RSLR projections for 2050 and 2100 in the RCP 2.6 and RCP 8.5 climatic scenarios. Finally, we analyzed LiDAR data to extract high resolution DEMs to obtain detailed maps of flooding scenarios.

\subsection{GNSS Data}

We used the available raw observations provided by GNSS-RING network [81], managed by INGV [82], integrated by other active GNSS stations belonging to regional and national networks [83], in order to estimate the VLM rates at a set of stations located within $10 \mathrm{~km}$ from the coastlines of south-eastern Sicily (Figure 2). In our analysis, we considered all the data available from 1995 to 2020, but, specifically, the sites shown in Figure 2 span the 2006-2020 time-interval. The analysis was performed by the GAMIT/GLOBK software, following the three step procedures described in Serpelloni et al. [29].

The raw GPS observables have been analysed using the GAMIT/GLOBK software (V.10.70) [84,85] adopting IGS standards [86]. In this step, the satellites orbit parameters are tightly constrained to the IGS final values. The GAMIT software estimates station positions, atmospheric delays, satellite orbits and Earth orientation parameters from ionosphere-free linear combination GPS phase observables using double differencing techniques in order to eliminate phase biases caused by drifts in the satellite and receiver clock oscillators. GPS pseudo-range observables are also used to constrain clock timing offsets and improving automated editing of phase data, helping in the resolution of integer phase ambiguities. GPS phase data are weighted adopting an elevation-angle-dependent error model [85]. The IGS absolute antenna phase centre model is used for both satellite and ground-based antennas, allowing us to improve the accuracy of vertical site positions by mitigating reference frame scale and atmospheric mapping function errors. While the first-order ionospheric delay is eliminated by the ionosphere-free linear combination, the second-order ionospheric corrections are applied using IONEX files from the Centre for Orbit Determination in Europe (CODE). The tropospheric delay is modelled as piecewise linear model and estimated using the Vienna Mapping Function 1 (VMF1). We use the Global Pressure and Temperature 2 (GPT2) model to provide a priori hydrostatic delays. The pole tide was also corrected in GAMIT adopting IERS standards. The Earth Orientation Parameters (EOP) are tightly constrained to priori values obtained from IERS Bulletin B. Ocean loading is corrected using the FES2004 model. The International Earth Rotation Service (IERS) 2003 model for diurnal and semi-diurnal solid Earth tides was set. Because of the large number of stations included in our Euro-Mediterranean GNSS data processing ( 3000), the GAMIT analysis is performed for several sub-networks, each made by $<50$ stations, with each sub-network sharing a set of high-quality IGS stations that are later used as tie-stations in the combination step.

The daily sub-nets, loosely constrained, solutions are combined using the GLOBK software, which adopts a Kalman filter estimation algorithm, simultaneously realizing a global reference frame by applying generalized constraints. Specifically, we define the reference frame by minimizing the velocities of the IGS core stations (http:/ /igscb.jpl.nasa. 
gov, accessed on 6 January 2021 [87]), while estimating a seven-parameter transformation with respect to the GPS realization of the ITRF2014 frame, i.e., the IGS14 reference frame.

In the third step, we analyse the position time series in order to estimate the 3components' (east, north and vertical) of linear velocities and uncertainties. Changes in stations positions are modelled using the following functional model:

$$
x(t)=x_{0}+b t+\alpha \sin (\omega t+\varphi)+\sum_{j=1}^{n} \Delta x_{j} H\left(t-t_{j}\right)
$$

where $x$ is the position of a point, $t$ is the time, $x_{0}$ is the initial position bias, $b$ is the secular rate, $\alpha$ and $\varphi$ are the amplitude and phase of the annual and semi-annual seasonal signals, respectively, and $H$ is the Heaviside step function defining coordinate jumps $(\Delta x)$ at a given time $t_{j}$. Only stations with a minimum time-span of 4.5 years are retained in this and subsequent analyses, in order to avoid biases due to unreliable estimated seasonal signals and underestimated velocity uncertainties due to absorbed correlated noise content in estimated trends of short time series. We estimate the stations rates uncertainties assuming a white-flicker noise model, using the approach implemented in the CHEETAH software [88].

\subsection{InSAR Technique and Data}

Since the 1990s, the Synthetic Aperture Radar Interferometry (InSAR) technique allowed the detection and measurements of crustal movements from space with unprecedented accuracy and spatial coverage [89,90]. The InSAR is a non-invasive technique [91], suitable to monitor large areas of the Earth's surface, measuring the projection of the deformation vector onto the Line of Sight (LoS) direction.

In the last 20 years, the increased availability of new SAR instruments and satellite constellations, has stimulated a steady improvement of processing algorithms. Several multi-temporal InSAR techniques have been proposed, exploiting the redundancy offered by hundreds of image pairs, i.e., hundreds of interferograms, to retrieve mean ground velocity and time-series of relative ground displacements. The existing algorithms fall into two broad categories, based on the Permanent Scatterer (PS) [92] and the Small Baseline (SB) [93] approaches, although more recently algorithms exploiting the basic principles of both methodologies have also been proposed [94].

In this study, we adopted the SBAS methodology applied along both the ascending and descending orbit of the Sentinel-1A satellites (C-Band SAR sensor wavelength=5.6 cm) operated by the European Space Agency (ESA) in the TOPSAR acquisition mode (VV polarization) and free-distributed (https: / / sentinel.esa.int/web/sentinel/missions/sentinel-1, accessed on 6 January 2021 [95]). Both the ascending and descending SAR datasets have been processed using the Geohazard Exploitation Platform (GEP, https:/ / geohazards-tep.eu/, accessed on 6 January 2021 [96]) and the P-SBAS service, implemented therein. An initial multi-looking operation was applied to the Single Look Complex images equal to 20 and 5 looks along the range and azimuth direction, respectively, resulting in a ground pixel resolution of 90 meters. The main processing steps of the SBAS approach consist of differential interferograms generation from the formed SAR image pairs with a small orbital separation (spatial baseline) to reduce the spatial decorrelation and topographic effects. The Shuttle Radar Topography Mission (SRTM) [97] with 1 arc-second ( 30 m pixel size) DEM from NASA and precise orbits from the European Space Agency (ESA) were used for the co-registration and for topographic phase removal from the interferometric phase on each of the compute interferograms. Then, a filtering operation is performed to improve the obtained interferogram's quality and make easier the following phase unwrapping step according to a fixed coherence threshold (equal to 0.7 for both the ascending and descending processing). Then, an inversion step is performed to put together the ground displacement time series in the time interval covered by the considered SAR acquisitions. At this stage, the atmospheric artifacts are also estimated and removed through a double 
filtering in the spatial and temporal domain (high and low pass filtering equal to 1200 meters and 365 days, respectively) [93,98]. Finally, the geocoding step is applied by means of the adopted DEM, obtaining a 90m ground pixel in the WGS84 datum to reference the displacements estimated for both the orbits.

In detail, we considered 60 images along the descending orbit (track 124) covering the time interval from 6 July 2017 to 8 March 2020 with a revisiting time of 12 days, enough to detect the movement in the investigated area, and resulting in 163 pairs. The same procedure was considered for the ascending case (track 44) selecting 103 images relative to the 3 October 2016-28 March 2020 temporal span and forming 290 interferograms. The retrieved InSAR ground velocity maps along the satellites LoS are showed in Figures 3 and 4 for the ascending and descending orbits, respectively.

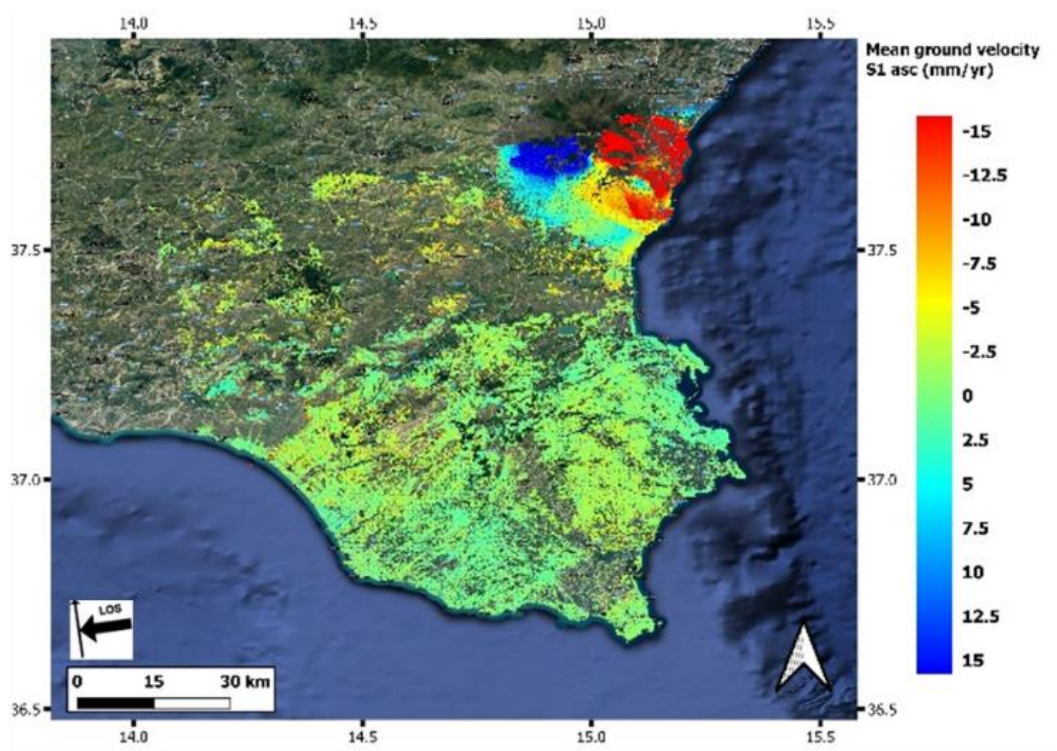

(a)

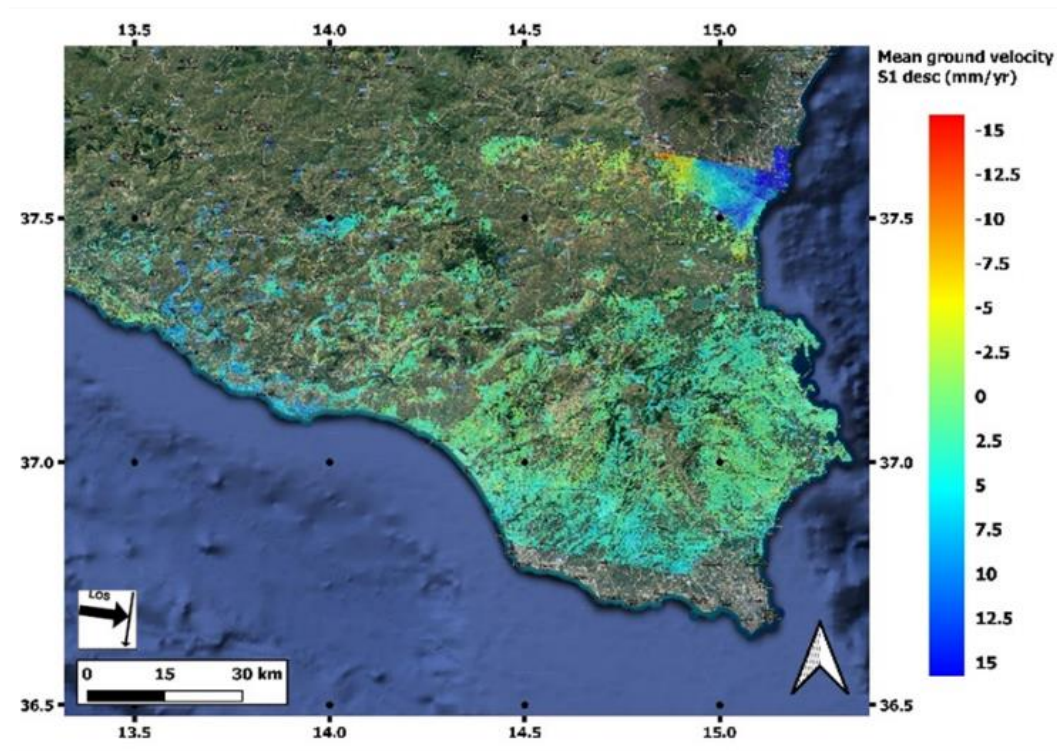

(b)

Figure 3. Land velocities (mm/year) estimated in the time span 2015-2020 from InSAR for (a) ascending and (b) descending orbits. The marked surface deformation observed in the northern part of the area is related to the effects of the volcanic and seismic activity occurred on Etna in December 2018. 

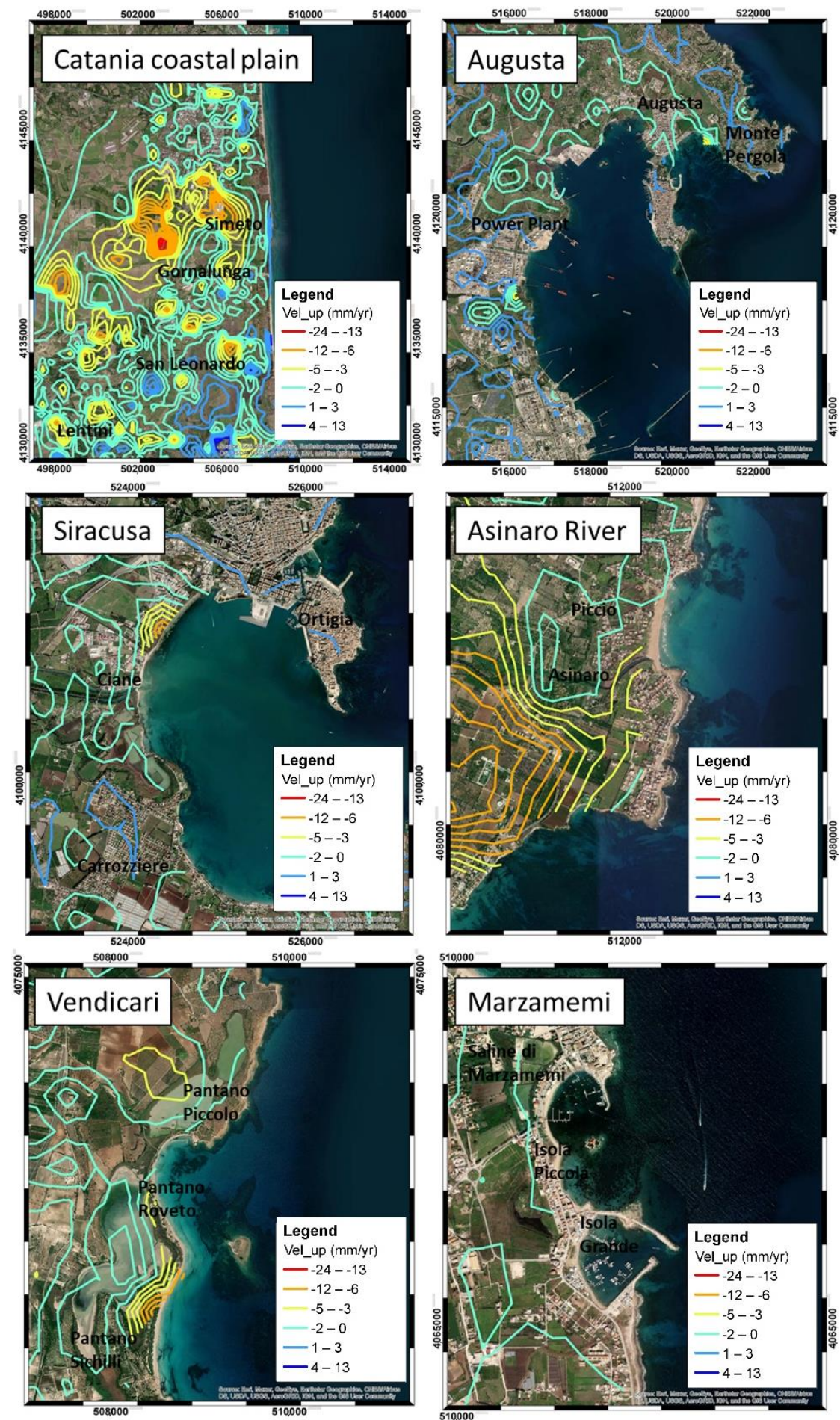

Figure 4. Vertical land velocities (contour in mm/year) estimated in the time span 2015-2020 from the combination of InSAR ascending and descending orbits, for six investigated coastal zones (see Figure 2 for location).

Thanks to the availability of both the ascending and descending InSAR outcomes, we retrieved the surface movement along the vertical and eastward directions. This can only be done for the pixels common to both the ascending and descending LoS maps.

Because of the SAR geometry acquisition, the east-west component of ground motion is proportional to the difference between descending and ascending LoS maps, and it is also a function of the local incidence angles of SAR; the vertical is proportional to the sum of the two datasets, and depends on the local incidence angles, too. Unfortunately, the north- 
south component of the ground movement has a little effect on the LoS measurements (less than $10 \%$ of the north-south movement is captured by SAR); therefore, we cannot estimate it. The analytical expression that we applied to calculate vertical and east-west motions is reported in Dalla Via [99].

Generally, ground movements along the coastal stripes are characterized by subsidence phenomena due to the coastal erosion and soil compaction causing as a consequence the retreat of the coastline $[80,100,101]$. Moreover, the tectonic regime of the area of interest foresees vertical movements, e.g., rise of marine terraces $[58,60,62,65]$. Therefore, the horizontal component of the retrieved LoS velocity is negligible in the areas investigated in this study (see also S1-Supplementary Material).

InSAR products were validated and calibrated through a comparison with the GNSS data superimposed and projected on the InSAR LoS directions, for both the orbits (see S1Additional Material for further information). Such decomposition was made pursuant to the InSAR and GNSS data comparison and validation; hence, the reported Up component already include any post-processing performed operation to calibrate InSAR products (see S1-Additional Material for further details).

\subsection{Sea-Level Data}

The analysis of sea-level data collected at the tidal networks located in the Mediterranean basin highlighted a mean rate of sea-level rise of about $1.8 \mathrm{~mm} /$ year for the last two-three centuries [70], although local VLMs can influence, even severely, the mean trend [102]. The closest tide gauge station in the investigated area of south eastern Sicily is located in the harbor of Catania (ISPRA tidal network, www.mareografico.it, accessed on 1 January 2021 [103]). The analysis of the time series of monthly mean sea-level data collected in the time span 1992-2020, shows a trend at $4.66 \pm 0.01 \mathrm{~mm}$ /year (Figure 5), which is about $2.9 \mathrm{~mm} /$ year higher than the average rate for the Mediterranean Sea. It is worth noting that InSAR analysis detected a local land subsidence at about $2 \mathrm{~mm} /$ year in the proximity of the coast of Catania (Figures 3 and 4) that affects sea-level recordings. In addition, RSLR for this location could be exacerbated by additional subsidence due local instabilities of the tidal station location being placed at the top of a large pier in the Catania harbor (Station coordinates Lat $37^{\circ} 29^{\prime} 44.42^{\prime \prime} \mathrm{N}$; Long $15^{\circ} 05^{\prime} 42.11^{\prime \prime} \mathrm{E}$ ).

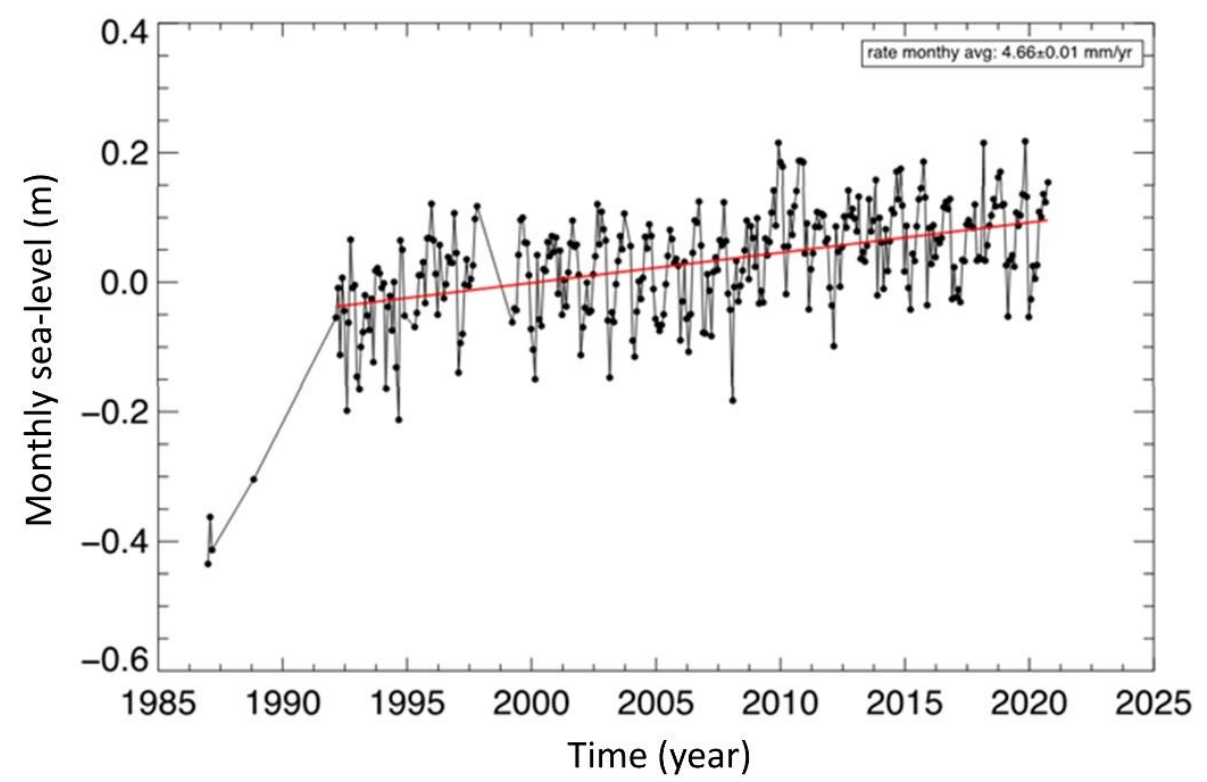

Figure 5. Monthly sea-level at the tide gauge station of Catania in the time span 1986-2020. The linear trend (red line), calculated in the time interval 1992-2020, corresponds to a rate of $4.66 \mathrm{~mm} /$ year. Recordings between 1986 and 1992 have been excluded in the analysis due to a relocation of the station. 
In order to project the expected sea-levels at 2050 and 2100 A.D. for the coast of south eastern Sicily, the novel sea-level projections based on the IPCC special report "The Ocean and Cryosphere in a Changing Climate (SROCC)" [7], released in 2019, were adopted. SROCC estimates consist of sea-level median values and standard errors on a worldwide grid obtained by summing up the contributions of geophysical sources driving long-term sea-level changes. The considered sources of sea-level variations are: the thermosteric/dynamic contribution (from the same 21 CMIP5 coupled atmosphereocean general circulation models AOGCMs used for AR5 IPCC projections), the surface mass balance and dynamic ice sheet from Greenland and Antarctica, the glacier and land water storage, the glacial isostatic adjustment (GIA) and the inverse barometer effect. As for the AR5 IPCC, SROCC projections are provided for three different RCPs 2.6, 4.5 and 8. 5: in the RCP 2.6 scenario the emissions of greenhouse-gas emission peak around 2020, in RCP 8.5 they continue to grow throughout the century [104]. SROCC and AR5 IPCC sea-level projections only differ in the estimates of the contributions from Antarctica: new ice-sheet modelling results, not available at the time of AR5, have been incorporated into the SROCC assessment. The difference between global mean sea-levels in SROCC and AR5 IPCCS is negligible under RCP 2.6 and RCP 4.5 scenarios while it is about $10 \mathrm{~cm}$ in 2100 under RCP 8.5.

The predicted sea-level rise in the south-eastern margin of Sicily has been estimated by combining the rate of sea-level rise at the grid point closest to Lat $37^{\circ} 2^{\prime} 54.32^{\prime \prime} \mathrm{N}$; Lon $15^{\circ} 17^{\prime} 50.51^{\prime \prime} \mathrm{E} \mathrm{Gr}$, as provided by the SROCC projections, with the rate of vertical land motion inferred from InSAR data. In details, the measured rate of vertical land motion, which includes both GIA and tectonic components of both natural and anthropogenic origin, replaces the GIA contribution used in the original SROCC projections. Errors coming from the InSAR data are included in the overall uncertainty estimation.

\subsection{Optical Satellite Images}

We used the time series of optical satellite images Landsat 7-8 [105] acquired in the time span 2001-2019 and multispectral WorldView 2 acquired in 2011 to evaluate the horizontal migration of the sandy shorelines that underwent to significant retreat. The effective shoreline migration was obtained following the method described in Scardino et al. [80]. From all the selected images, the shorelines were digitalized in GIS environment for each year reported in the satellite images. In the coastal areas affected by several meters of coastal retreat, an estimation of the rate of total shoreline retreat was performed.

To this aim, we applied a linear regression of the shoreline position digitalized with respect to years of the satellite images. This approach involves the coastal retreat as a result of all contribution that cause the sediment movements and shoreline migration. Firstly, to assess the coastal retreat only due to SLR contribution, we assumed the investigated coasts to be in steady-state approach, without significant sediment movements and the shoreline migration caused only by land subsidence estimated by the geodetic measurements. Secondly, the eustatic sea-level component was added to the local land subsidence analysis to obtain horizontal displacements in function of the coastal slope. The latter has been extracted from DEM of LiDAR data. The most relevant shoreline changes have been observed on the coastal plain of Catania, the sandy coast of Siracusa and the coast of Vendicari, near Marzamemi (Figure 6).

To project the shoreline migration at 2050 and 2100 epochs, we incorporated the sealevel projections in the model reported in Scardino et al. [80]. Starting from the present-day coastline extracted from high-resolution satellite image of ESRI ArcGIS service (year 2019), the coastline in 2050 and 2100 was mapped. 

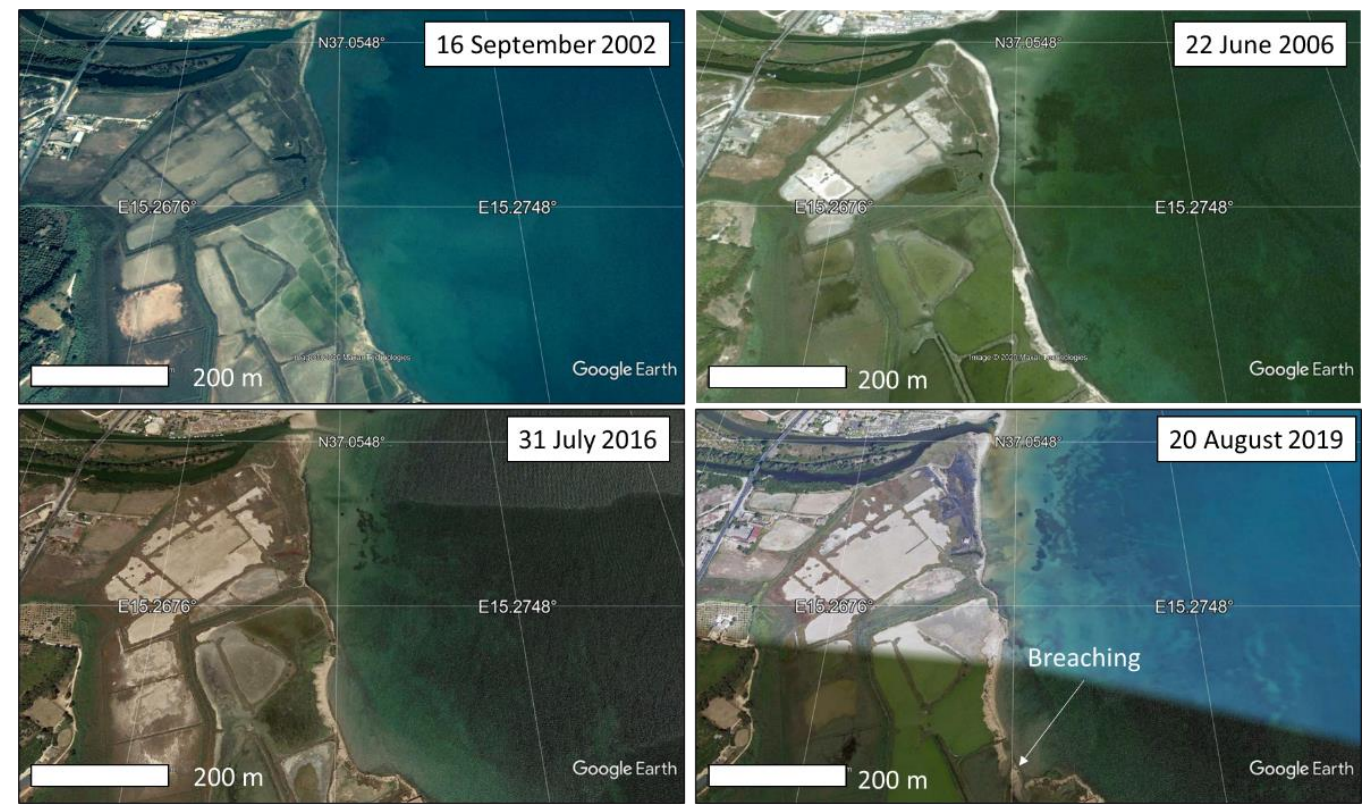

Figure 6. Multi-temporal shoreline changes observed along at the mouth of Ciane river in the time span 16 September 2002-20 August 2019. In 2019, the southern sector of the beach has been affected by a foredune breaching. In 17 years, the coast retreated up to $70 \mathrm{~m}$ due to the effect of RSLR with a loss of surface of $0.07 \mathrm{~km}^{2}$.

\subsection{Digital Elevation Model (DEM)}

The present-day topography was obtained by the analysis of airborne LiDAR (Light Detection and Ranging) observation data collected by the Regione Sicilia in 2008-2009 [106] and georeferenced in EPSG 3004 Monte Mario Italy 2. The DEM was extracted with $2 \times 2 \mathrm{~m}$ cell width and a mean vertical resolution of about $20 \mathrm{~cm}$. The rates of VLM estimated by InSAR data have been represented as contour lines on the Digital Elevation Models (DEMs), by means of ArcGIS ${ }^{\circledR}$ and Global Mapper software (www.globalmapper.com (accessed on 1 January 2021) [107]. 3D high-resolution maps of the investigated area were produced, on which the position of the present-day coastline and its potential position in 2100 as a result of relative sea-level rise are shown by contour lines and colour-shaded options, defining the upper limits of the exposed zones at potential sea flooding by 2100 for different climatic scenarios. DEMs were analysed to obtain the elevation of the coastal areas and the slope of the mobile coastal systems. To model the changes of the local topography at 2050 and 2100, elevations on DEM cells were corrected with the displacements of digital model VLM in 2050 and 2100. 3D high-resolution maps of the investigated area were produced for the topography in 2050 and 2100, on which the position of the present-day coastline and its potential future position in response to the relative sea-level rise, defining the upper limits of the exposed zones at potential sea flooding.

\section{Results and Discussion}

Since the last decade, new studies primarily based on IPCC projections, started to provide future sea-level rise assessments along the global coasts, generally without considering the contribution of VLM [1,108]. Lambeck et al. [30], Antonioli et al. [31]; Marsico et al. [79] and Antonioli et al. [32], constrained the spatially variable VLMs based on long-term geological data (mainly the elevation of the marine terraces of the MIS 5.5) to obtain RSLR scenarios for 2100 along low-lying coasts of the Italian peninsula. Recently, instrumental data from GNSS networks, InSAR observations and tide gauges have been considered in these projections for the realization of inundation hazard maps in several areas such as the coasts of California [34] and specific coasts of Italy [11,17,32,71,77,80,109,110], assuming that VLM rates measured by geodetic instruments will remain constant in the coming decades in a specific coastal zone. 
Our results underline the importance of a multidisciplinary approach for the RSLR assessment to predict the future submersion of investigated coasts. The multi-temporal maps of the expected submersion for 2050 and 2100 have been obtained through an integrated analysis of SLR projections, VLMs and the detailed representation of the shoreline migrations on high resolution DEMs. The conceptual approach is based on the worst conditions for a mobile coastal system, in which the coastal resilience is not sufficient to contrast the sea-level rise. Such conditions are particularly evident in the coastal areas characterized by low sediment supply and retreatment of the river mouths (for example the Simeto river mouth, Figure 7). Moreover, strong subsidence could act locally, preventing the dynamical response of the coastal system. A negative contribution that affects the Southeastern Sicily coasts is due to the anthropogenic factors [111], which determined the decrease of sediment supply and fluid withdrawal. Obviously, in the attempt to propose a future scenario, it is necessary to make some hypotheses and, in our case, it has been assumed that the ground deformation is linear over time. This velocity rate is considered to be constant and equal to that obtained from 4 years of monitoring with SAR data. This assumption is considered valid as the GNSS data also confirm that over a much longer temporal period (more than 20 years). Furthermore, we showed how the vertical displacement retrieved by the two remote sensing techniques, e.g., InSAR and GNSS, are comparable as well confirming our starting assumption. Finally, considering the tectonic regime of the area, we can state that most of the observed vertical velocities recorded at the GNSS stations show tectonic stability, with the exception in the north of Catania, near the Etna volcano. On the other hand, the low rate of land subsidence recorded south of Catania, fit the GIA values for this region, which have been estimated between -0.5 and $-1 \mathrm{~mm} /$ year [29].
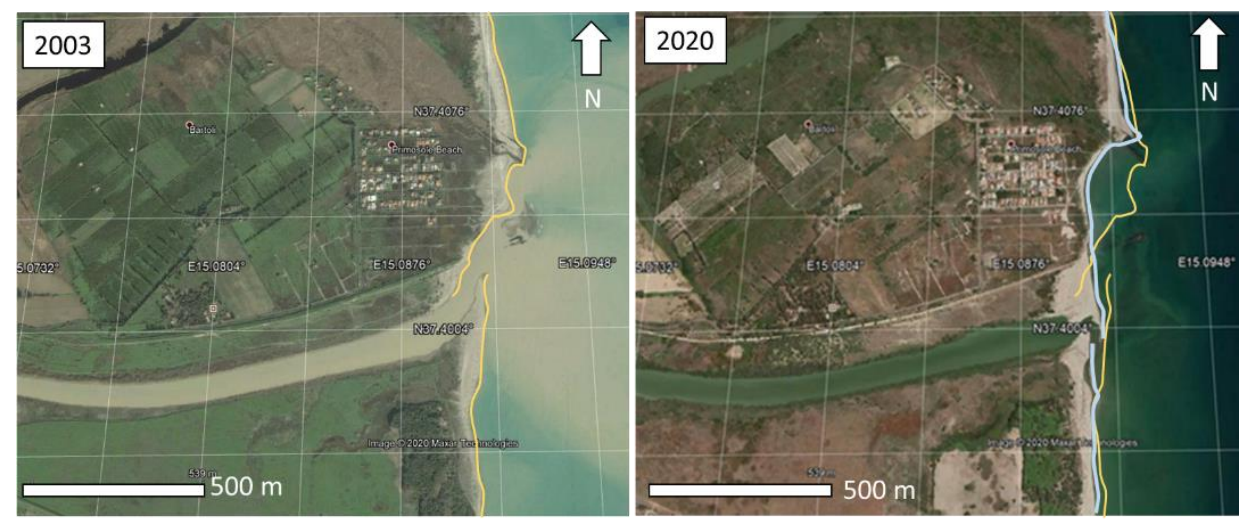

Figure 7. Retreat of the Simeto river mouth on the Catania coastal plain. The shoreline at 2003 epoch is marked in light orange (left) while the shoreline for 2020 epoch is marked in light blue (right).

Results highlight the contribution of sea-level rise to the shoreline retreat at a level lower than 35\% (Figure 8). Below are reported the estimated shoreline changes for a set of coastal zones:

Catania coastal plain. A variable shoreline change was estimated between 6.34 and $3.23 \mathrm{~m} /$ year (with a linear regression of $4.78 \pm 2 \mathrm{~m} /$ year). In the proximity of the Simeto, Gurnazza and San Leonardo river mouths a fast shoreline retreat, up to $10 \mathrm{~m} /$ year, was observed [111]. The southern part of the coastal plain influences large subsidence, reaching a rate up to $8 \pm 2.46 \mathrm{~mm} /$ year in the Lentini area. The mobile coastal system showed phase of decrease of sediment supply, particularly over the last decades. The reduction of suspended load from Simeto, Gurnazza and San Leonardo determined a negative sedimentary balance, which is exacerbated by the intense beach-dune erosion. 


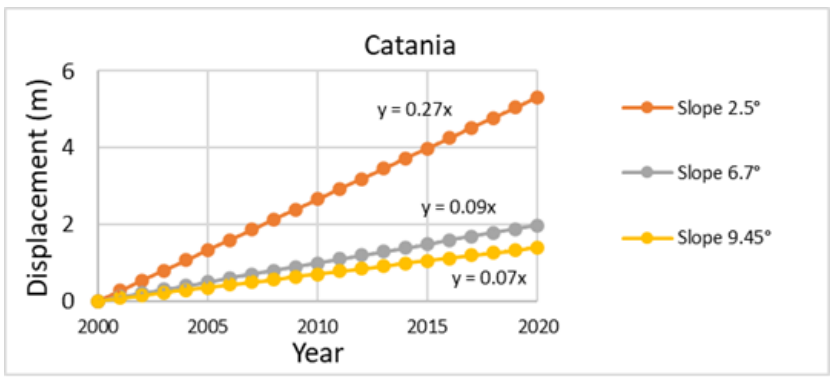

(a)

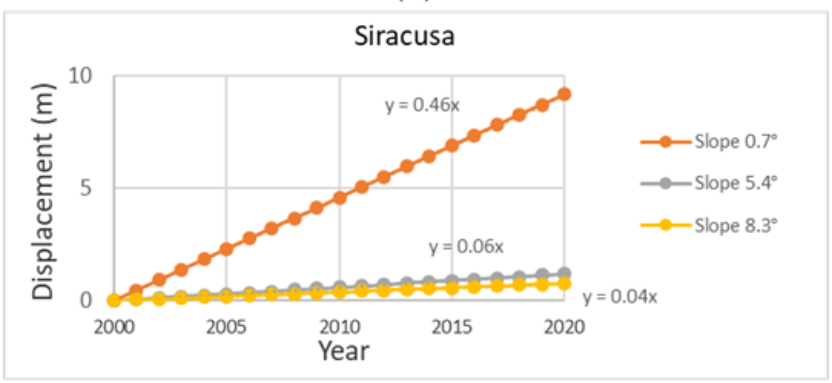

(b)

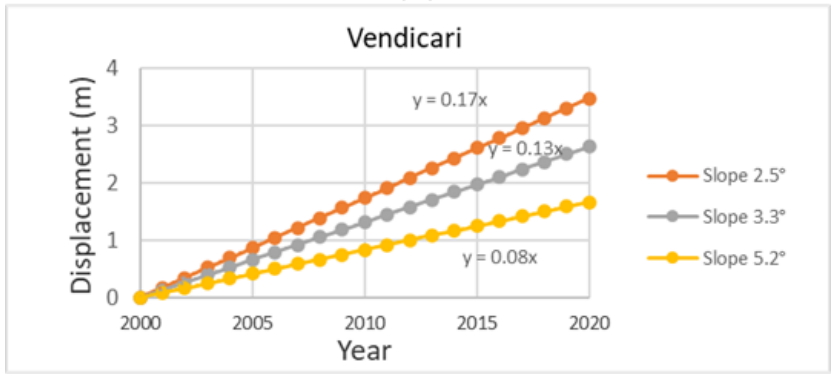

(c)

Figure 8. $(\mathbf{a}-\mathbf{c})$ Horizontal displacements obtained following a geometric steady-state approach: sea-level rise determines a landward shoreline movement without accretion, where the shoreline rate change is dependent only on the coastal slope extracted from the DEM of LiDAR data.

The sandy coast of Siracusa. This coastal zone shows a rate of shoreline changes between 4.01 and $3.9 \mathrm{~m} /$ year (linear regression rate of $4 \pm 1.9 \mathrm{~m} /$ year). The main evidence of shoreline changes occurred south of the Ciane river mouth. This area, which is characterized by salt-marshes, has been affected by a coastline retreat of about $70 \mathrm{~m}$, with local breaching of the beach-dune system (Figure 6). The salt-marsh is subsiding at about $2 \pm 2.46 \mathrm{~mm} /$ year, while the northern sector of this coast, displays higher subsidence rates mainly located in the Siracusa harbor, with velocities of about $5 \pm 2 \mathrm{~mm}$ /year. The narrow beaches that separate the salt-marsh from the sea are not nourished by inland sediments due to dams that highly reduce the supply of sediments on the coast.

The coast of Vendicari. This area shows a rate of shoreline retreat between 0.95 and $0.4 \mathrm{~m} /$ year, with a mean rate of $0.68 \pm 0.4 \mathrm{~m} /$ year. The InSAR analysis showed significant rates of local land subsidence, at about $-4 \pm 2.46 \mathrm{~mm} /$ year. Foredune system showed a given stability over the last few decades, while the dynamic of the coasts seems to be correlated to the longshore drift toward south.

Figure 9 and Table 1 show reference RSLR projections for RCP 2.6 and RCP 8.5 for the investigated coastal zones most prone to SLR in 2050 and 2100. 


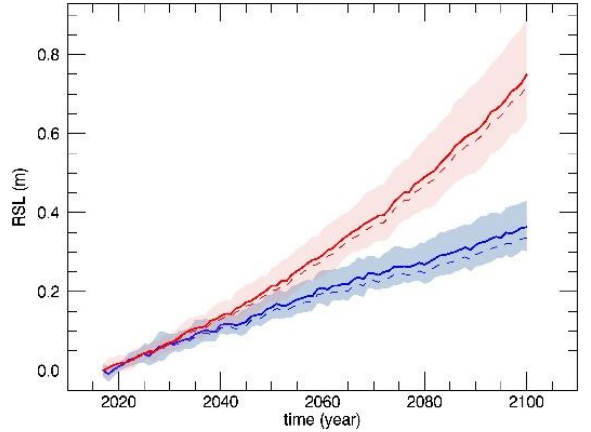

(a)

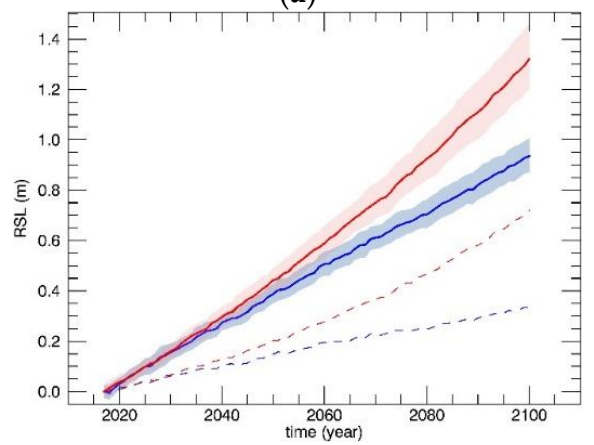

(c)

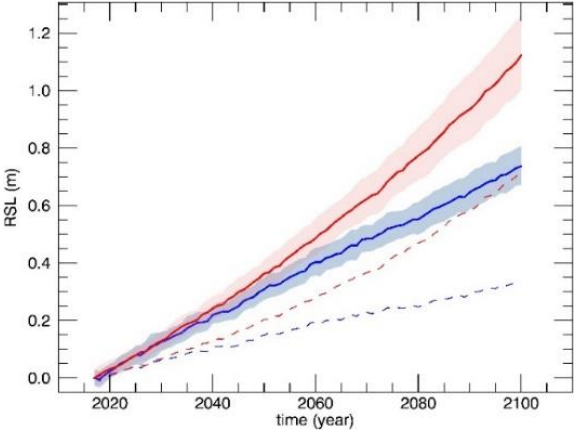

(b)

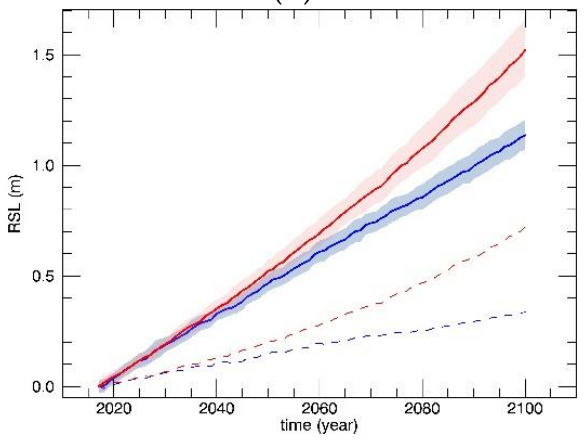

(d)

Figure 9. Sea-level projections relative to 2016 AD for the coast of South-eastern Sicily obtained by combining the IPCCSROCC 2019 projections at regional scales with the contribution of the most common rates of land subsidence as derived from InSAR analysis (Figures 10-15): (a) $0.7 \pm 0.35 \mathrm{~mm} /$ year; (b) $5.2 \pm 2.5 \mathrm{~mm} /$ year; (c) $7.6 \pm 2.5 \mathrm{~mm} /$ year and (d) $10 \pm 2.5 \mathrm{~mm} /$ year. Full lines correspond to the 2.6 (blue) and 8.5 (red) SROCC scenarios and the coloured bands highlight the $90 \%$ confidence interval. Dashed lines correspond to the raw SROCC projections when no measured vertical land motion is included. The small-scale variations observed in the data are related to the ocean component contribution accounting for the effects of dynamic SSH, the global thermosteric SSH anomaly and inverse barometer effects.

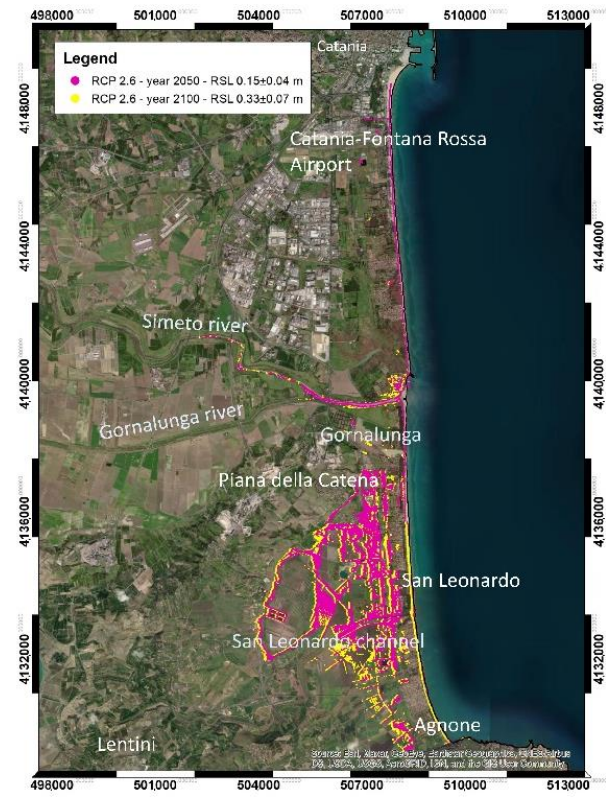

(a)

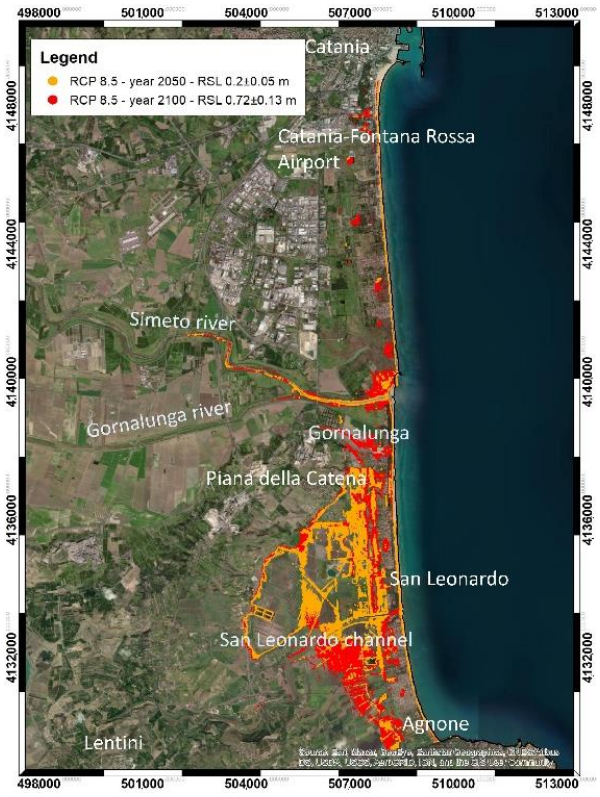

(b)

Figure 10. The Catania coastal plain. In color are reported the expected extension of flooding in 2050 and 2100 for (a) RCP2.6 and (b) RCP8.5 emission scenarios, respectively. The expected maximum loss of land in 2100 is $4.094 \mathrm{~km}^{2}$ (high-resolution maps are inserted in Supplementary Materials Maps S2 and S3). The coastal strip is characterized by about null VLM $(-0.7 \pm 0.35 \mathrm{~mm} /$ year $)$ with respect to the inner zones that show subsidence rates exceeding $10 \pm 2.5 \mathrm{~mm} /$ year, likely due to local fluid withdrawal. 


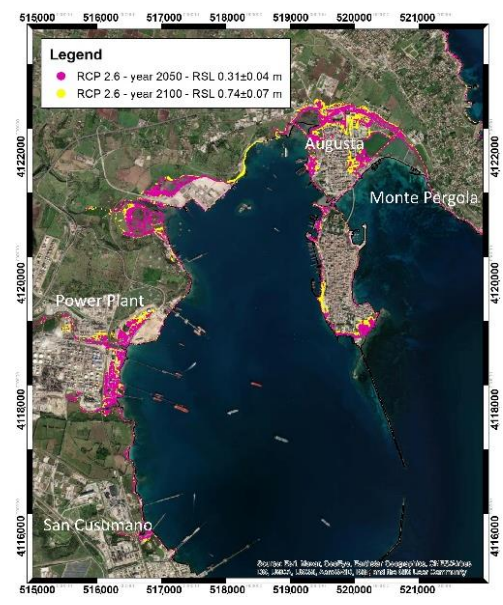

(a)

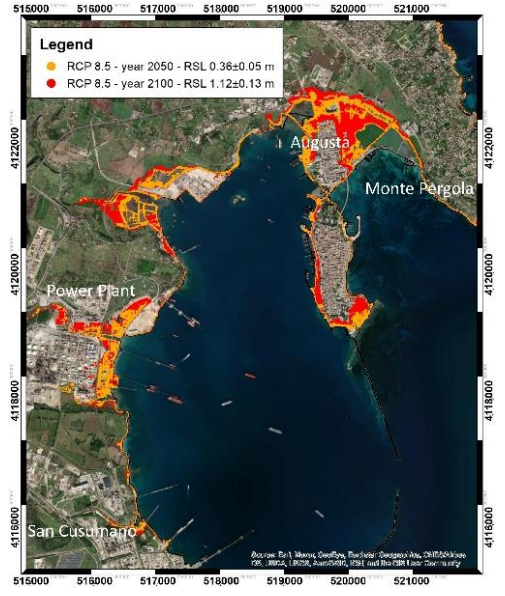

(b)

Figure 11. The bay of Augusta. In colors are reported the expected extension of land flooding in 2050 and 2100 for (a) RCP 2.6 and (b) RCP 8.5 climatic scenarios for a mean land subsidence at $3.4 \pm 2.5 \mathrm{~mm}$ /year. The expected maximum loss of land is $1.659 \mathrm{~km}^{2}$ (high-resolution maps are inserted in Supplementary Materials Maps S4 and S5).
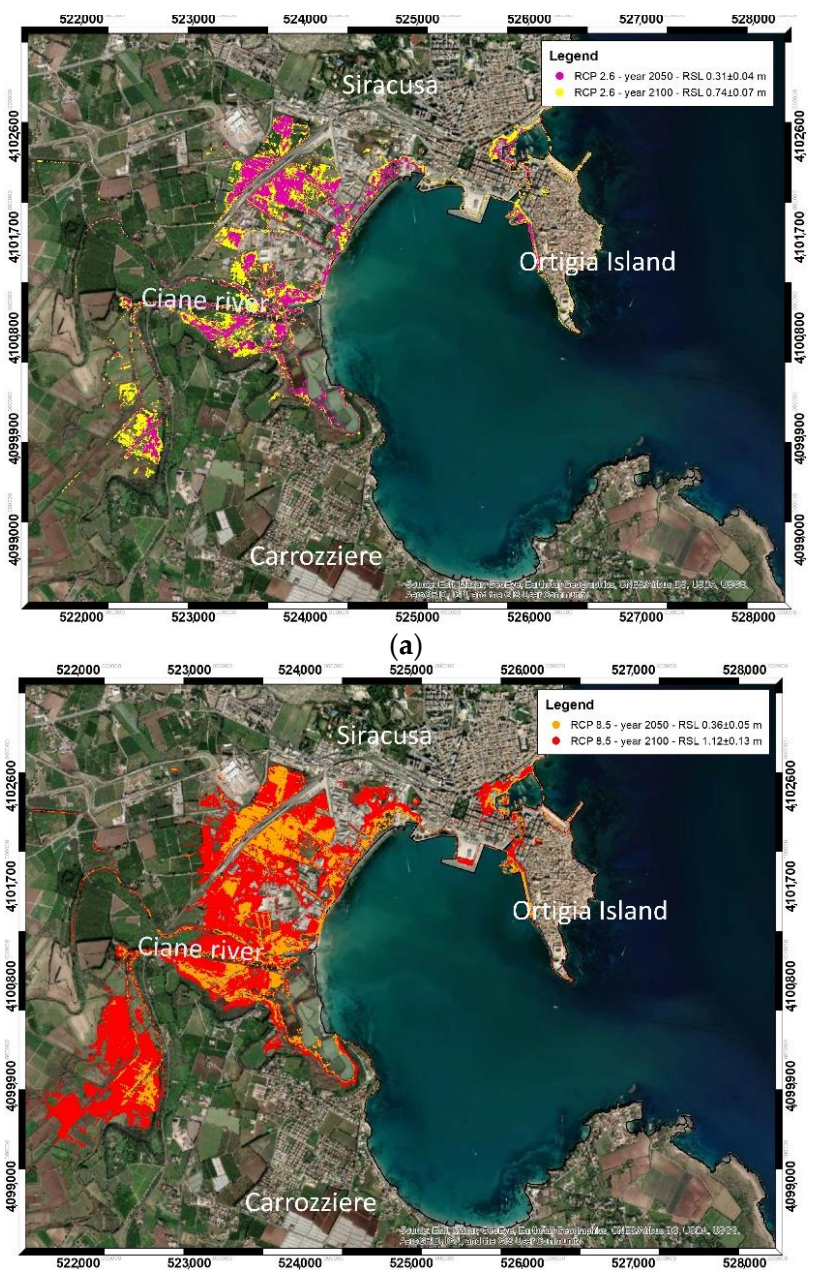

(b)

Figure 12. The bay of Siracusa. In colors are reported the expected extension of land flooding in 2050 and 2100 for (a) RCP 2.6 and (b) RCP 8.5 climatic scenarios for a mean land subsidence at $7 \pm 2.5 \mathrm{~mm} /$ year. The expected maximum loss of land is $2.378 \mathrm{~km}^{2}$ (high-resolution maps are inserted in Supplementary Materials Maps S6 and S7). 


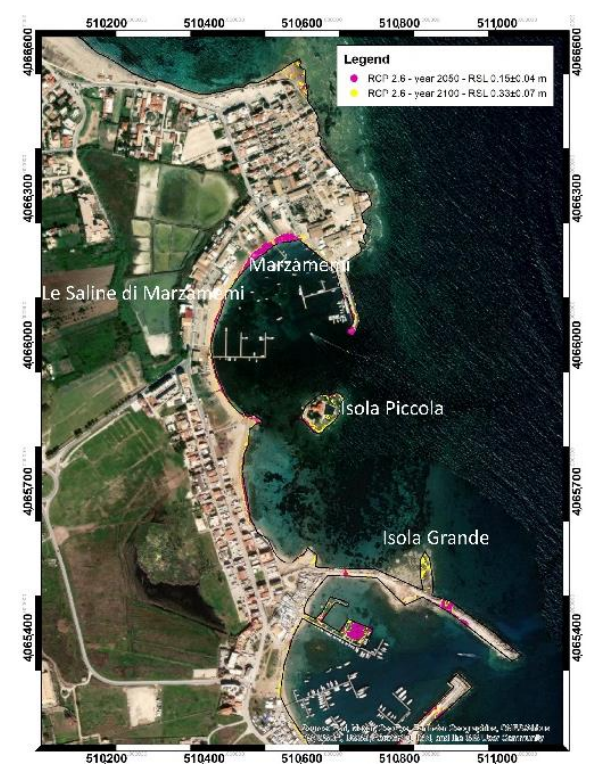

(a)

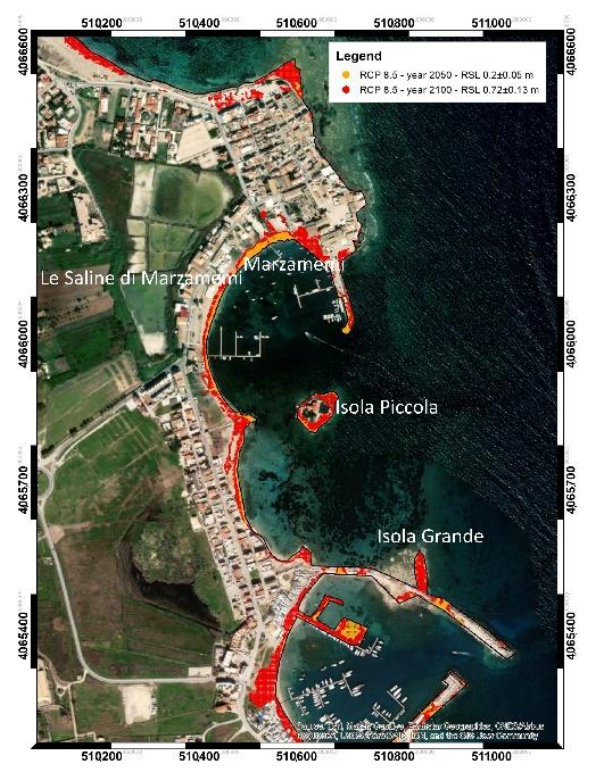

(b)

Figure 13. The coast of Marzamemi. In colors are reported the expected extension of flooding in 2050 and 2100 for (a) RCP 2.6 and (b) RCP 8.5 climatic scenarios. The expected maximum loss of land is $0.043 \mathrm{~km}^{2}$ (high-resolution maps are inserted in Supplementary Materials Maps S8 and S9). VLM are about null except for the area of the modern harbor (at the bottom in the figure), which is affected by a subsidence at $1.02 \pm 2.5 \mathrm{~mm} /$ year.

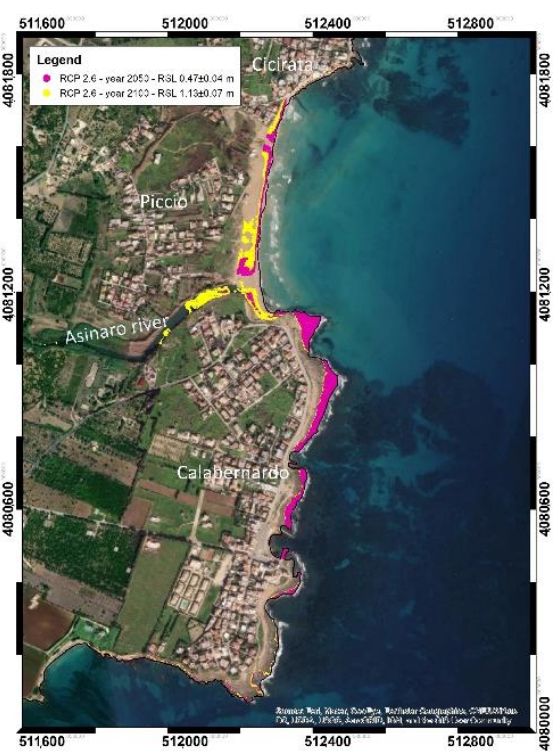

(a)

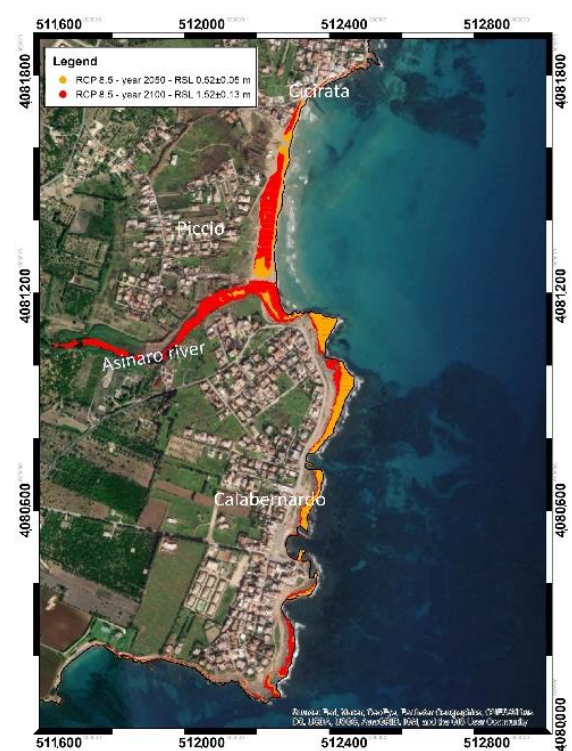

(b)

Figure 14. The bay of the Asinaro river mouth, near Piccio. In colors are reported the expected extension of land flooding in 2050 and 2100 for (a) RCP 2.6 and (b) RCP 8.5 climatic scenarios for a mean land subsidence at $8 \pm 2.5 \mathrm{~mm} /$ year. The expected maximum loss of land is $0.045 \mathrm{~km}^{2}$ (high-resolution maps are inserted in Supplementary Materials Maps S10 and S11). 


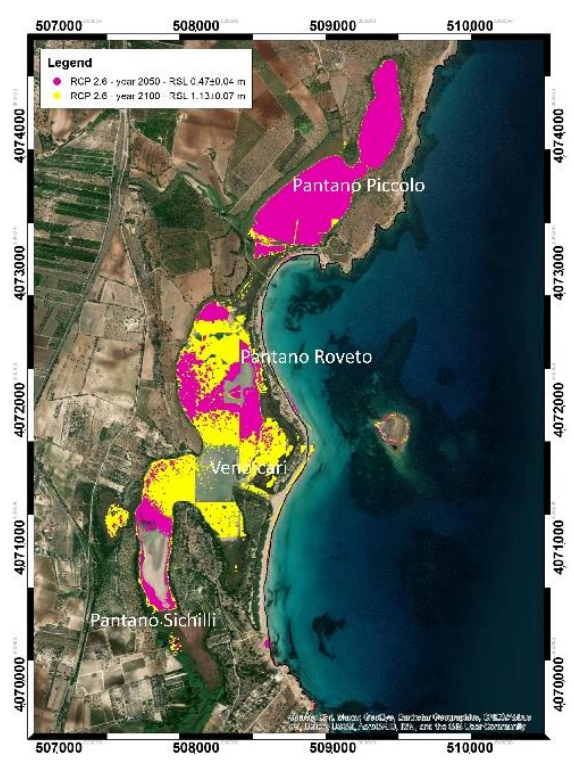

(a)

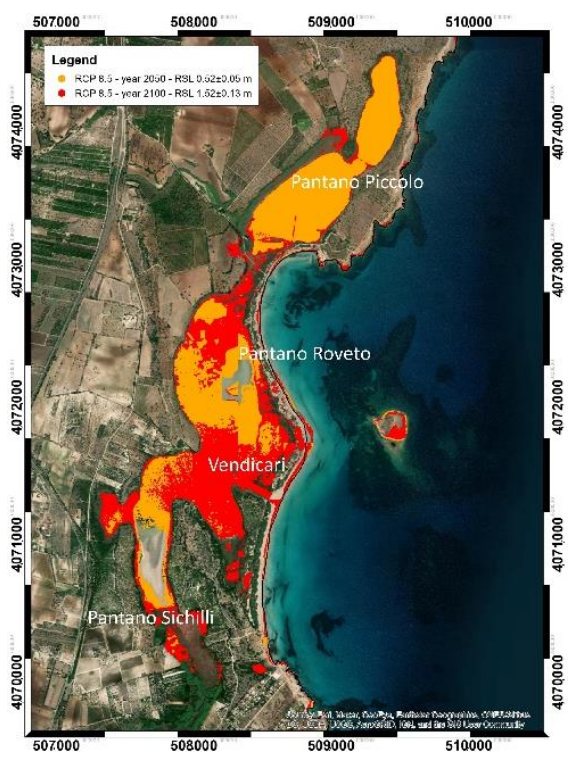

(b)

Figure 15. The bay of Vendicari. In colors are reported the expected extension of land flooding in 2050 and 2100 for (a) RCP 2.6 and (b) RCP 8.5 climatic scenarios for a mean land subsidence at $4 \pm 2.5 \mathrm{~mm}$ /year. Maximum rate of land subsidence for this area is $10 \pm 2.5 \mathrm{~mm} /$ year. The expected maximum loss of land is $1.528 \mathrm{~km}^{2}$ (high-resolution maps are inserted in Supplementary Materials Maps S12 and S13).

Table 1. Relative sea-levels projections for RCP 2.6 and RCP 8.5 scenarios for 2050 and 2100 with respect to 2016, for different VLM rates observed in this study in south-eastern Sicily. Uncertainties define the $90 \%$ confidence limits. Different cases are considered for: (i) null vertical land motion (only the contribution of GIA already included in the SROCC projections is considered); (ii) mean VLM at $-0.7 \pm 0.35 \mathrm{~mm}$ /year derived by GNSS data and (iii) observed values of VLM estimated by InSAR analysis along the coastal zones reported in Figure 5.

\begin{tabular}{ccccc}
\hline VLM (mm/year) & RCP 2.6 & RCP 2.6 & RCP 8.5 & RCP 8.5 \\
$\mathbf{2 0 5 0}(\mathbf{m})$ & $\mathbf{2 1 0 0}(\mathbf{m})$ & $\mathbf{2 0 5 0}(\mathbf{m})$ & $\mathbf{2 1 0 0}(\mathbf{m})$ \\
\hline Null VLM & $0.15 \pm 0.03$ & $0.33 \pm 0.06$ & $0.20 \pm 0.04$ & $0.72 \pm 0.13$ \\
GNSS: $-0.7 \pm 0.35$ & $0.16 \pm 0.03$ & $0.36 \pm 0.06$ & $0.21 \pm 0.04$ & $0.75 \pm 0.13$ \\
InSAR: $-2.0 \pm 2.5$ & $0.20 \pm 0.04$ & $0.47 \pm 0.07$ & $0.26 \pm 0.05$ & $0.86 \pm 0.13$ \\
InSAR: $-3.4 \pm 2.5$ & $0.25 \pm 0.04$ & $0.59 \pm 0.07$ & $0.30 \pm 0.05$ & $0.97 \pm 0.13$ \\
InSAR: $-5.2 \pm 2.5$ & $0.31 \pm 0.04$ & $0.74 \pm 0.07$ & $0.36 \pm 0.05$ & $1.12 \pm 0.13$ \\
InSAR: $-7.6 \pm 2.5$ & $0.39 \pm 0.04$ & $0.94 \pm 0.07$ & $0.44 \pm 0.05$ & $1.32 \pm 0.13$ \\
InSAR: $-8.0 \pm 2.5$ & $0.40 \pm 0.04$ & $0.97 \pm 0.07$ & $0.46 \pm 0.05$ & $1.35 \pm 0.13$ \\
InSAR: $-8.7 \pm 2.5$ & $0.42 \pm 0.04$ & $1.03 \pm 0.07$ & $0.48 \pm 0.05$ & $1.41 \pm 0.13$ \\
InSAR: $-10.0 \pm 2.5$ & $0.47 \pm 0.04$ & $1.13 \pm 0.07$ & $0.52 \pm 0.05$ & $1.52 \pm 0.13$ \\
\hline
\end{tabular}

Because the GNSS stations are often too sparse and far from the investigated areas (Figure 2), we preferred to use the VLM rates obtained from the InSAR analysis to assess the local VLM trend and to calculate the expected RSLR values. It is worth noting that the VLM velocities obtained from the InSAR data coincides with the GNSS velocities at the individual stations with an uncertainty of $\pm 2.5 \mathrm{~mm}$. The expected flooding scenarios reported in Figures 10-15 are based on VLM values shown in Figure 5. Maps are referred to the RCP 2.6 (low emission) and RCP 8.5 (high emission) climatic scenarios reported in the SROCC Report (Oppenheimer et al., [26]), for which SLR is accelerated by land subsidence as estimated by geodetic analysis. The multi-temporal coastal positions projected on the high-resolution topography extracted from LiDAR data, allow to detail the potential flooding extension and the related impacts on the investigated coasts (Table 2). For the RCP 8.5 emission scenario, the maximum extension of expected flooded area for 2100 A.D. in the investigated zone, is about $9.7 \mathrm{~km}^{2}$. 
Table 2. Expected RSLR (m) and extension $\left(\mathrm{km}^{2}\right)$ of the exposed flooded areas for 2050 and 2100 A.D. for RCP 2.6 and RCP 8.5 emission scenarios.

\begin{tabular}{|c|c|c|c|c|c|c|}
\hline Area & RSLR RCP 2.6 (m) & $\begin{array}{c}\text { RSLR RCP } 8.5 \\
\text { (m) }\end{array}$ & $\begin{array}{c}\text { RCP } 2.6 \\
2050\left(\mathrm{~km}^{2}\right)\end{array}$ & $\begin{array}{c}\text { RCP } 2.6 \\
2100\left(\mathrm{~km}^{2}\right)\end{array}$ & $\begin{array}{c}\text { RCP } 8.5 \\
2050\left(\mathrm{~km}^{2}\right)\end{array}$ & $\begin{array}{c}\text { RCP } 8.5 \\
2100\left(\mathrm{~km}^{2}\right)\end{array}$ \\
\hline Catania plain & $\begin{array}{l}\text { 2050: } 0.15 \pm 0.03 \\
\text { 2100: } 0.33 \pm 0.06\end{array}$ & $\begin{array}{l}\text { 2050: } 0.20 \pm 0.04 \\
\text { 2100: } 0.72 \pm 0.13\end{array}$ & 1.21 & 2.634 & 1.762 & 4.092 \\
\hline Augusta & $\begin{array}{l}\text { 2050: } 0.31 \pm 0.04 \\
\text { 2100: } 0.74 \pm 0.07\end{array}$ & $\begin{array}{l}\text { 2050: } 0.36 \pm 0.05 \\
\text { 2100: } 1.12 \pm 0.13\end{array}$ & 0.275 & 0.668 & 0.433 & 1.659 \\
\hline Siracusa & $\begin{array}{l}\text { 2050: } 0.31 \pm 0.04 \\
\text { 2100: } 0.74 \pm 0.07\end{array}$ & $\begin{array}{l}\text { 2050: } 0.36 \pm 0.05 \\
\text { 2100: } 1.12 \pm 0.13\end{array}$ & 0.393 & 0.951 & 0.544 & 2.378 \\
\hline $\begin{array}{l}\text { Asinaro river } \\
\text { mouth }\end{array}$ & $\begin{array}{l}\text { 2050: } 0.47 \pm 0.04 \\
2100: 1.13 \pm 0.07\end{array}$ & $\begin{array}{l}\text { 2050: } 0.52 \pm 0.05 \\
\text { 2100: } 1.52 \pm 0.13\end{array}$ & 0.015 & 0.021 & 0.017 & 0.043 \\
\hline Vendicari & $\begin{array}{l}\text { 2050: } 0.47 \pm 0.04 \\
\text { 2100: } 1.13 \pm 0.07\end{array}$ & $\begin{array}{l}\text { 2050: } 0.52 \pm 0.05 \\
\text { 2100: } 1.52 \pm 0.13\end{array}$ & 0.675 & 1.047 & 0.837 & 1.528 \\
\hline Marzamemi & $\begin{array}{l}\text { 2050: } 0.15 \pm 0.04 \\
\text { 2100: } 0.33 \pm 0.07\end{array}$ & $\begin{array}{c}\text { 2050: } 0.2 \pm 0.05 \\
\text { 2100: } 0.72 \pm 0.13\end{array}$ & 0.007 & 0.013 & 0.010 & 0.045 \\
\hline & Total extension & & 2.58 & 5.33 & 3.60 & 9.75 \\
\hline
\end{tabular}

The potential extension of the flooded area depends on the topographic features and the expected RSLR. The largest flooding is expected in the coastal plain of Catania and the Lentini area, where the complex topography and the San Leonardo channel can drive a marine ingression up to $5 \mathrm{~km}$ inland, both for the RCP 2.6 and 8.5 scenarios (Figure 10).

In the Augusta bay, the expected extension of the potential flooded area is relevant in the northern sector, reaching up to $500 \mathrm{~m}$ and $1 \mathrm{~km}$ inland for the RCP 2.6 and RCP 8.5 scenario, respectively (Figure 11). The most important flooding is expected for the coast of Siracusa, where the flooded area will possibly extend for more than $2 \mathrm{~km}$ inland in both RCP scenarios (Figure 12), involving the local salt-marsh, part of the city and the railways. The RSLR scenario for the pocket beach of Piccio, located in the proximity of Asinaro river mouth (Figures 13-15), is less critical both for the RCP 2.6 and RCP 8.5 scenarios, but still with a partial submersion of the backshore.

The natural reserve of Vendicari is exposed to a potential flooding extending up to $1 \mathrm{~km}$ inland, involving the lagoons of Pantano Roveto and Pantano Piccolo (Figure 12). The expected RSLR in Marzamemi bay, may cause a flooding extension of about $300 \mathrm{~m}$ inland (Figure 13), determining the potential loss of the foreshore and backshore and leading to the abandonment of the historical fisherman village.

Concerning the role of the dune system in counteracting the SLR, field evidence and optical satellite images show that over the last two decades, the beach-dune systems have been subjected to a continuous retreat in consequence of multiple factors (Table 3), mainly, the sea-level rise, the increasing intensity of extreme marine events, VLM and deficit on the sediment supply in a coastal system. The high rates of land subsidence highlighted by InSAR, suggest that future scenarios could be driven by overtopping processes, rollover or dune breaching [112,113], probably similar in timing and architecture of resulting deposits, to retrogradation processes occurred during the marine transgression after the last glacial maximum (LGM) in different low-gradient settings [114-116]. In particular, the time series of satellite images of the sandy coasts at Siracusa between 2009 and 2020 (Figure 8, Table 3), show the occurrence of dune breaching near the salt-marshes over the last decades. Considering the expected accelerated SLR trend in the RCP 8.5 emission scenario, the beachdune system will be more vulnerable in the next years with respect to the past decades due the combined effects of SLR, VLM and negative mass balance on the coasts. 
Table 3. Shoreline changes for different slopes (column C) for three sandy coasts located at Catania, Siracusa and Vendicari (Column A). The difference between the total observed shoreline retreat (due to the sea-level rise, the increasing intensity of extreme marine events, VLM and deficit on the sediment supply in a coastal system-column D) and the retreat due to RSLR only (column E, geometric horizontal retreat), defines the residual shoreline change (D-E). The coastal erosion triggered by RSLR is the predominant effect in the shoreline change process for the analysed gentle sloping sandy coasts which are retreating at up to $4.78 \mathrm{~m}$ /year.

\begin{tabular}{|c|c|c|c|c|c|}
\hline A & B & $\mathrm{C}$ & D & E & $\mathbf{F}$ \\
\hline Sandy coasts & $\begin{array}{l}\text { VLM InSAR, } \\
\text { (mm/year) }\end{array}$ & $\begin{array}{l}\text { Coastal slope } \\
\text { (degree) }\end{array}$ & $\begin{array}{l}\text { Total shoreline } \\
\text { retreat (m/year) }\end{array}$ & $\begin{array}{l}\text { RSLR shoreline } \\
\text { retreat (m/year) }\end{array}$ & $\begin{array}{l}\text { Residual shoreline } \\
\text { change (D-E) } \\
\text { (m/year) }\end{array}$ \\
\hline Catania & $-8 \pm 2.5$ & $\begin{array}{c}2.5 \\
6.7 \\
9.45 \\
0.7\end{array}$ & -4.78 & $\begin{array}{l}-0.27 \\
-0.09 \\
-0.07 \\
-0.46\end{array}$ & $\begin{array}{l}-4.51 \\
-4.69 \\
-4.71 \\
-3.55\end{array}$ \\
\hline Siracusa & $-2 \pm 2.5$ & $\begin{array}{c}5.38 \\
8.3 \\
2.5\end{array}$ & -4.01 & $\begin{array}{l}-0.06 \\
-0.04 \\
-0.17\end{array}$ & $\begin{array}{l}-3.95 \\
-3.97 \\
-0.51\end{array}$ \\
\hline Vendicari & $-4 \pm 2.5$ & $\begin{array}{l}2.5 \\
3.3 \\
10\end{array}$ & -0.68 & $\begin{array}{l}-0.17 \\
-0.13 \\
-0.08\end{array}$ & $\begin{array}{l}-0.51 \\
-0.55 \\
-0.6\end{array}$ \\
\hline
\end{tabular}

If sea-level will continue to rise at accelerated rates, it is reasonable to expect a corresponding accelerated erosion that will strike severely the coastal system. The increasing coastal hazard will facilitate the marine flooding with subsequent impacts of the coastal zone, including saltwater contamination of surface and underground waters, wetland losses, and increased flooding which may lead to relevant socioeconomic impacts.

An additional factor, acting in combination with RSLR, is the occurrence of extreme marine events connected to storm and tropical-like system (Medicanes). Several models showed that the future storm events will be more intense than today [117-120], and the combined effect of wave flooding and sea-level rise could increase the coastal vulnerability, with loss of surfaces greater than those shown in Figures 10-15. Moreover, the intensity of tropical-like system is increasing in the Mediterranean [19,121-123], leading to extreme marine events that in conjunction with RSLR could determine several meters of inland flooding.

\section{Conclusions}

The methodological approach here presented to account for SLR and coastal land subsidence is transferable to other coastal zones and can be used to inform land planners and decisions makers that should take into account similar scenarios for a cognizant coastal management. The ongoing global climate change is affecting the inundation risks both through accelerating ice sheet melting (i.e., increasing the rate of eustatic SLR) and through more intense droughts, leading to unprecedented groundwater overexploiting and associated localized coastal land subsidence. Because climate change and SLR are posing unprecedented threats to the coastal environment, urbanization and population, multidisciplinary studies that include Earth Observations in combination with ground data and SLR projections will provide crucial information on the evolution of the coastal zones and their future expected shape.

Our results have shown that the area underwent to coastal retreat up to $70 \mathrm{~m}$ in a few years only while diffuse land subsidence is locally exceeding $10 \pm 2.5 \mathrm{~mm} /$ year, due to compaction of artificial landfill, salt marshes and Holocene soft deposits. Given the ongoing land subsidence, the estimated high end of RSLR at $0.52 \pm 0.05 \mathrm{~m}$ and $1.52 \pm 0.13 \mathrm{~m}$ expected for $2050 \mathrm{AD}$ and $2100 \mathrm{AD}$ in the RCP 8.5 scenario, will lead up to about $10 \mathrm{~km}^{2}$ of marine flooding. The inundation scenarios we have presented should be considered for a cognizant management of the coastal zone in response to the ongoing climate changes. 
Major consequences of inundation risk for the coastal areas of south-eastern Sicily include saltwater contamination of surface and underground waters, accelerated coastal erosion, wetland and saltmarshes losses and, in general, increased flooding. These effects are all related with the ongoing global warming and may lead to unprecedented socioeconomic impacts. Our analysis can improve flood resilience plans for an area of the Mediterranean with significant populations and infrastructures exposed to flood risk that can be exacerbated by storm surges, earthquakes, tsunamis and volcano-tectonic activity.

Supplementary Materials: The following are available online at https:/ / www.mdpi.com/2072-429 2/13/6/1108/s1, S1-Supplementary Materials; Maps: S2-S12. Captions of Supplementary Materials: S1-Supplementary Materials. The description of the InSAR results validation. Maps S2. The Catania coastal plain: expected flooding in 2050 and 2100 for RCP 2.6 projections. Maps S3. The Catania coastal plain: expected flooding in 2050 and 2100 for RCP 8.5 projections. Maps S4. The bay of Augusta: expected flooding in 2050 and 2100 for RCP 2.6 projections. Maps S5. The bay of Augusta: expected flooding in 2050 and 2100 for RCP 8.5 projections. Maps S6. The bay of Siracusa: expected flooding in 2050 and 2100 for RCP 2.6 projections. Maps S7. The bay of Siracusa: expected flooding in 2050 and 2100 for RCP 8.5 projections. Maps S8. The coast of Marzamemi: expected flooding in 2050 and 2100 for RCP 2.6 projections. Maps S9. The coast of Marzamemi: expected flooding in 2050 and 2100 for RCP 8.5 projections. Maps S10. The Asinaro river mouth: expected flooding in 2050 and 2100 for RCP 2.6 projections. Maps S11. The Asinaro river mouth: expected flooding in 2050 and 2100 for RCP 8.5 projections. Maps S12. The bay of Vendicari: expected flooding in 2050 and 2100 for RCP 2.6 projections. Maps S13. The bay of Vendicari: expected flooding in 2050 and 2100 for RCP 8.5 projections.

Author Contributions: Conceptualization, M.A., Giovanni Scicchitano; methodology, M.A., G.S. (Giovanni Scardino), C.B., C.T., E.S., V.D.S., A.V.; software, M.A., G.S. (Giovanni Scardino), C.B., C.T., E.S., A.V., V.D.S.; validation, M.A., G.S. (Giovanni Scicchitano), C.M., M.M., G.M.; formal analysis, A.V.; C.M., G.M.; investigation, M.A., G.S. (Giovanni Scicchitano); resources, M.A., G.S. (Giovanni Scicchitano), G.M.; data curation, G.S. (Giovanni Scicchitano), G.S. (Giovanni Scardino), C.T., C.B., E.S., A.V.; writing—original draft preparation, M.A., G.S. (Giovanni Scicchitano); writing-review and editing, M.A., G.S. (Giovanni Scicchitano), (Giovanni Scardino); visualization, A.P., M.M., G.M.; supervision, M.A., G.S. (Giovanni Scicchitano), G.M.; project administration, M.A., G.S. (Giovanni Scicchitano), G.M.; funding acquisition, M.A., G.M. All authors have read and agreed to the published version of the manuscript.

Funding: Please add: This research was partially funded by (i) Progetto Pianeta Dinamico, Task A2-2020 under the umbrella of MIUR 2020-2030 program; (ii) savemedcoasts (Agreement number ECHO/SUB/2016/742473/PREV16) and savemedcoasts-2 (Project number 874398) EU Projects (www.savemedcoasts.eu; www.savemedcoasts2.eu, accessed on 10 January 2021); (iii) I-STORMS Project from DISTEGEO-UNIBA and Regione Puglia Civil Protection (resp. G. Mastronuzzi); (iv) the Italian ministry of University and Research (MIUR), grant number INGV 1020.010 law 145/2018, "Fondo finalizzato al rilancio degli investimenti delle amministrazioni centrali dello Stato e allo sviluppo del Paese".

Data Availability Statement: Copernicus Sentinel-1 IW SAR data were provided via and processed in ESA's Geohazards Thematic Exploitation Platform (Geohazards TEP, or GEP), in the framework of the GEP Early Adopters Programme and the Geohazards Lab initiative, the latter developed under the CEOS Working Group on Disasters. SAR data processing was carried out using the P-SBAS on-demand service developed and integrated by CNR-IREA in GEP. Post-processing and analysis were carried out with ESRI ArcGIS Desktop v.10.5.0, licensed to INGV. LiDAR data were provided by WMS service of Regione Sicilia. GNSS data are retrieved, processed and archived by the INGV Geodetic analysis data center. Tide gauge data for the sea-level station of Catania are freely available at www.mareografico.it (accessed on 21 January 2021).

Acknowledgments: We are thankful to the Carlo Doglioni who supported this study through the project Pianeta Dinamico (managed by Guido Ventura and Paolo Augliera). This research benefited from the methodology developed in SAVEMEDCOASTS and SAVEMEDCOASTS2 projects, both funded by the EU under the umbrella of the DGECHO.

Conflicts of Interest: The authors declare no conflict of interest. 


\section{References}

1. Vermeer, M.; Rahmstorf, S. Global sea level linked to global temperature. Proc. Natl. Acad. Sci. USA 2009, 106, $21527-21532$. [CrossRef]

2. Kemp, A.C.; Horton, B.P.; Donnelly, J.P.; Mann, M.E.; Vermeer, M.; Rahmstorf, S. Climate related sea-level variations over the past two millennia. Proc. Natl. Acad. Sci. USA 2011, 108, 11017-11022. [CrossRef] [PubMed]

3. Meyssignac, B.; Cazenave, A. Sea level: A review of present-day and recent-past changes and variability. J. Geodyn. 2012, 58, 96-109. [CrossRef]

4. Jevrejeva, S.; Moore, J.; Grinsted, A.; Matthews, A.; Spada, G. Trends and acceleration in global and regional sea levels since 1807. Glob. Planet. Chang. 2014, 113, 11-22. [CrossRef]

5. Woppelmann, G.; Marcos, M. Coastal sea level rise in southern Europe and the nonclimate contribution of vertical land motion. J. Geophys. Res. Space Phys. 2012, 117. [CrossRef]

6. Dangendorf, S.; Marcos, M.; Wöppelmann, G.; Conrad, C.P.; Frederikse, T.; Riva, R. Reassessment of 20th century global mean sea level rise. Proc. Natl. Acad. Sci. USA 2017, 114, 5946-5951. [CrossRef] [PubMed]

7. IPCC. Special Report on the Ocean. and Cryosphere in a Changing Climate; Pörtner, H.-O., Roberts, D.C., Masson-Delmotte, V., Zhai, P., Tignor, M., Poloczanska, E., Mintenbeck, K., Alegría, A., Nicolai, M., Okem, A., et al., Eds.; Working Group II Technical Support Unit: Geneva, Switzerland, 2019.

8. Garner, A.J.; Weiss, J.L.; Parris, A.; Kopp, R.E.; Horton, R.M.; Overpeck, J.T.; Horton, B.P. Evolution of 21st Century Sea Level Rise Projections. Earth's Future 2018, 6, 1603-1615. [CrossRef]

9. Vecchio, A.; Anzidei, M.; Serpelloni, E.; Florindo, F. Natural Variability and Vertical Land Motion Contributions in the Mediterranean Sea-Level Records over the Last Two Centuries and Projections for 2100. Water 2019, 11, 1480. [CrossRef]

10. Addo, K.A.; Larbi, L.; Amisigo, B.; Ofori-Danson, P.K. Impacts of Coastal Inundation Due to Climate Change in a CLUSTER of Urban Coastal Communities in Ghana, West Africa. Remote Sens. 2011, 3, 2029-2050. [CrossRef]

11. Anzidei, M.; Bosman, A.; Carluccio, R.; Casalbore, D.; Caracciolo, F.D.; Esposito, A.; Nicolosi, I.; Pietrantonio, G.; Vecchio, A.; Carmisciano, C.; et al. Flooding scenarios due to land subsidence and sea-level rise: A case study for Lipari Island (Italy). Terra Nova 2017, 29, 44-51. [CrossRef]

12. Albert, S.; Leon, J.X.; Grinham, A.R.; Church, J.A.; Gibbes, B.R.; Woodroffe, C.D. Interactions between sea-level rise and wave exposure on reef island dynamics in the Solomon Islands. Environ. Res. Lett. 2016, 11, 054011. [CrossRef]

13. Mörner, N.-A.; Tooley, M.; Possnert, G. New perspectives for the future of the Maldives. Glob. Planet. Chang. 2004, 40, 177-182. [CrossRef]

14. Woodruff, J.D.; Irish, J.L.; Camargo, S.J. Coastal flooding by tropical cyclones and sea-level rise. Nat. Cell Biol. 2013, 504, 44-52. [CrossRef] [PubMed]

15. Toimil, A.; Camus, P.; Losada, I.; Le Cozannet, G.; Nicholls, R.; Idier, D.; Maspataud, A. Climate change-driven coastal erosion modelling in temperate sandy beaches: Methods and uncertainty treatment. Earth Sci. Rev. 2020, 202, 103110. [CrossRef]

16. Garner, A.J.; Mann, M.E.; Emanuel, K.A.; Kopp, R.E.; Lin, N.; Alley, R.B.; Horton, B.P.; DeConto, R.M.; Donnelly, J.P.; Pollard, D. Impact of climate change on New York City's coastal flood hazard: Increasing flood heights from the preindustrial to $2300 \mathrm{CE}$. Proc. Natl. Acad. Sci. USA 2017, 114, 11861-11866. [CrossRef] [PubMed]

17. Anzidei, M.; Doumaz, F.; Vecchio, A.; Serpelloni, E.; Pizzimenti, L.; Civico, R.; Greco, M.; Martino, G.; Enei, F. Sea Level Rise Scenario for 2100 A.D. in the Heritage Site of Pyrgi (Santa Severa, Italy). J. Mar. Sci. Eng. 2020, 8, 64. [CrossRef]

18. Savemedcoasts. Available online: http://www.savemedcoasts.eu/ (accessed on 4 April 2020).

19. Scicchitano, G.; Scardino, G.; Tarascio, S.; Monaco, C.; Barracane, G.; Locuratolo, G.; Milella, M.; Piscitelli, A.; Mazza, G.; Mastronuzzi, G. The First Video Witness of Coastal Boulder Displacements Recorded during the Impact of Medicane "Zorbas" on Southeastern Sicily. Water 2020, 12, 1497. [CrossRef]

20. Cid, A.; Menéndez, M.; Castanedo, S.; Abascal, A.J.; Méndez, F.J.; Medina, R. Long-term changes in the frequency, intensity and duration of extreme storm surge events in southern Europe. Clim. Dyn. 2015, 46, 1503-1516. [CrossRef]

21. Amores, A.; Marcos, M.; Carrió, D.S.; Gómez-Pujol, L. Coastal impacts of Storm Gloria (January 2020) over the north-western Mediterranean. Nat. Hazards Earth Syst. Sci. 2020, 20, 1955-1968. [CrossRef]

22. Lambeck, K.; Anzidei, M.; Antonioli, F.; Benini, A.; Esposito, A. Sea level in Roman time in the Central Mediterranean and implications for recent change. Earth Planet. Sci. Lett. 2004, 224, 563-575. [CrossRef]

23. Lambeck, K.; Purcell, A. Sea-level change in the Mediterranean Sea since the LGM: Model predictions for tectonically stable areas. Quat. Sci. Rev. 2005, 24, 1969-1988. [CrossRef]

24. IPCC. Climate Change 2013: The Physical Science Basis. Contribution of Working Group I to the Fifth Assessment Report of the Intergovernmental Panel on Climate Change; Stocker, T.F., Qin, D., Plattner, G.-K., Tignor, M., Allen, S.K., Boschung, J., Nauels, A., Xia, Y., Bex, V., Midgley, P.M., Eds.; Cambridge University Press: Cambridge, UK, 2013; p. 1535.

25. Dixon, T.H.; Amelung, F.; Ferretti, A.; Novali, F.; Rocca, F.; Dokka, R.; Sella, G.; Kim, S.-W.; Wdowinski, S.; Whitman, D. Subsidence and flooding in New Orleans. Nat. Cell Biol. 2006, 441, 587-588. [CrossRef] [PubMed]

26. Oppenheimer, M.; Bruce, G.; Jochen, H.; van de Wal, R.S.W.; Alexandre, A.; Abd-Elgawad, A.; Cai, R.; Cifuentes-Jara, M.; de Conto, R.; Tuhin, G.; et al. Sea Level Rise and Implications for Low Lying Islands, Coasts and Communities. In IPCC Special Report on the Ocean and Cryosphere in a Changing Climate; Pörtner, H.-O., Roberts, D.C., Masson-Delmotte, V., Zhai, P., Tignor, M., Poloczanska, E., Mintenbeck, K., Alegría, A., Nicolai, M., Okem, A., Eds.; IPCC: Geneva, Switzerland, 2019; p. 126. 
27. Chiarabba, C.; Jovane, L.; di Stefano, R. A new view of Italian seismicity using 20 years of instrumental recordings. Tectonophysics 2005, 395, 251-268. [CrossRef]

28. Lista Terremoti Aggiornata in Tempo Reale INGV Osservatorio Nazionale Terremoti. Available online: http://iside.rm.ingv.it/ (accessed on 6 January 2021).

29. Serpelloni, E.; Faccenna, C.; Spada, G.; Dong, D.; Williams, S.D.P. Vertical GPS ground motion rates in the Euro-Mediterranean region: New evidence of velocity gradients at different spatial scales along the Nubia-Eurasia plate boundary. J. Geophys. Res. Solid Earth 2013, 118, 6003-6024. [CrossRef]

30. Lambeck, K.; Antonioli, F.; Anzidei, M.; Ferranti, L.; Leoni, G.; Scicchitano, G.; Silenzi, S. Sea level change along the Italian coast during the Holocene and projections for the future. Quat. Int. 2011, 232, 250-257. [CrossRef]

31. Antonioli, F.; Anzidei, M.; Amorosi, A.; Presti, V.L.; Mastronuzzi, G.; Deiana, G.; de Falco, G.; Fontana, A.; Fontolan, G.; Lisco, S.; et al. Sea-level rise and potential drowning of the Italian coastal plains: Flooding risk scenarios for 2100. Quat. Sci. Rev. 2017, 158, 29-43. [CrossRef]

32. Antonioli, F.; de Falco, G.; Presti, V.L.; Moretti, L.; Scardino, G.; Anzidei, M.; Bonaldo, D.; Carniel, S.; Leoni, G.; Furlani, S.; et al. Relative Sea-Level Rise and Potential Submersion Risk for 2100 on 16 Coastal Plains of the Mediterranean Sea. Water 2020, 12, 2173. [CrossRef]

33. Griggs, G.; Árvai, J.; Cayan, D.; de Conto, R.; Fox, J.; Fricker, H.; Kopp, R.E.; Tebaldi, G.; Whiteman, E.A. Rising Seas in California: An Update on Sea-Level Rise Science. Calif. Ocean Sci. Trust 2017, 1, 1-71.

34. Shirzaei, M.; Bürgmann, R. Global climate change and local land subsidence exacerbate inundation risk to the San Francisco Bay Area. Sci. Adv. 2018, 4, eaap9234. [CrossRef]

35. Palano, M.; Ferranti, L.; Monaco, C.; Mattia, M.; Aloisi, M.; Bruno, V.; Cannavò, F.; Siligato, G. GPS velocity and strain fields in Sicily and southern Calabria, Italy: Updated geodetic constraints on tectonic block interaction in the central Mediterranean. $J$. Geophys. Res. Space Phys. 2012, 117. [CrossRef]

36. Ventura, B.M.; Serpelloni, E.; Argnani, A.; Bonforte, A.; Bürgmann, R.; Anzidei, M.; Baldi, P.; Puglisi, G. Fast geodetic strain-rates in eastern Sicily (southern Italy): New insights into block tectonics and seismic potential in the area of the great 1693 earthquake. Earth Planet. Sci. Lett. 2014, 404, 77-88. [CrossRef]

37. Grasso, M.; Lentini, F. Sedimentary and tectonic evolution of the eastern Hyblean Plateau (southeastern Sicily) during late Cretaceous to Quaternary time. Palaeogeogr. Palaeoclim. Palaeoecol. 1982, 39, 261-280. [CrossRef]

38. Scandone, P.; Patacca, E. Mesozoic and Cenozoic Rocks from Malta Escarpment (Central Mediterranean). AAPG Bull. 1981, 65, 1299-1319. [CrossRef]

39. Hirn, A.; Nicolich, R.; Gallart, J.; Laigle, M.; Cernobori, L.; ETNASEIS Scientific Group. Roots of Etna volcano in faults of great earthquakes. Earth Planet. Sci. Lett. 1997, 148, 171-191. [CrossRef]

40. Bianca, M.; Monaco, C.; Tortorici, L.; Cernobori, L. Quaternary normal faulting in southeastern Sicily (Italy): A seismic source for the 1693 large earthquake. Geophys. J. Int. 1999, 139, 370-394. [CrossRef]

41. Monaco, C.; Tapponnier, P.; Tortorici, L.; Gillot, P. Late Quaternary slip rates on the Acireale-Piedimonte normal faults and tectonic origin of Mt. Etna (Sicily). Earth Planet. Sci. Lett. 1997, 147, 125-139. [CrossRef]

42. Monaco, C.; Tortorici, L. Active faulting in the Calabrian arc and eastern Sicily. J. Geodyn. 2000, 29, 407-424. [CrossRef]

43. Gambino, S.; Barreca, G.; Gross, F.; Monaco, C.; Krastel, S.; Gutscher, M.-A. Deformation Pattern of the Northern Sector of the Malta Escarpment (Offshore SE Sicily, Italy): Fault Dimension, Slip Prediction, and Seismotectonic Implications. Front. Earth Sci. 2021, 8, 8. [CrossRef]

44. Postpischl, D.C. Catalogo dei Terremoti Italiani Dall'anno 1000 al 1980; P.F. Geodinamica, Graficoop.; Consiglio Nazionale Delle Ricerche, Progetto Finalizzato Geodinamica, Sottoprogetto Rischio Sismico e Ingegneria Sismica: Bologna, Italy, 1985.

45. Boschi, E.; Guidoboni, E.; Ferrari, G.; Valensise, G.; Gasperini, P. Catalogo dei forti terremoti in Italia dal 461 a.C. al 1990. ING-SGA Bologna 1997, 2, 644 .

46. Valensise, G.; Pantosti, D. The investigation of potential earthquake sources in peninsular Italy: A review. J. Seism. 2001, 5, 287-306. [CrossRef]

47. Azzaro, R.; Barbano, M.S. Analysis of the Seismicity of Southeastern Sicily: A Proposed Tectonic Interpretation. Ann. Geophys. 2000, 43. [CrossRef]

48. Tinti, S.; Armigliato, A. The use of scenarios to evaluate the tsunami impact in southern Italy. Mar. Geol. 2003, 199, 221-243. [CrossRef]

49. Serpelloni, E.; Bürgmann, R.; Anzidei, M.; Baldi, P.; Ventura, B.M.; Boschi, E. Strain accumulation across the Messina Straits and kinematics of Sicily and Calabria from GPS data and dislocation modeling. Earth Planet. Sci. Lett. 2010, 298, 347-360. [CrossRef]

50. Brancato, A.; Hole, J.A.; Gresta, S.; Beale, J.N. Determination of Seismogenic Structures in Southeastern Sicily (Italy) by HighPrecision Relative Relocation of Microearthquakes. Bull. Seism. Soc. Am. 2009, 99, 1921-1936. [CrossRef]

51. Achilli, V.; Anzidei, M.; Baldi, P.; Broccio, F.; Velardita, R. The Southeastern Sicily GPS Network. Ann. Geophys. 1995, 38. [CrossRef]

52. Amato, A.; Azzara, R.; Basili, A.; Chiarabba, C.; Cocco, M.; Bona, M.D.; Selvaggi, G. Main Shock and Aftershocks of the December 13, 1990, Eastern Sicily Earthquake. Ann. Geophys. 1995, 38. [CrossRef]

53. Westaway, R. Quaternary uplift of southern Italy. J. Geophys. Res. Space Phys. 1993, 98, 21741-21772. [CrossRef]

54. Wortel, M.J.R. Subduction and Slab Detachment in the Mediterranean-Carpathian Region. Science 2000, 290, 1910-1917. [CrossRef] 
55. Goes, S.; Giardini, D.; Jenny, S.; Hollenstein, C.; Kahle, H.-G.; Geiger, A. A recent tectonic reorganization in the south-central Mediterranean. Earth Planet. Sci. Lett. 2004, 226, 335-345. [CrossRef]

56. Gvirtzman, Z.; Nur, A. Residual topography, lithospheric structure and sunken slabs in the central Mediterranean. Earth Planet. Sci. Lett. 2001, 187, 117-130. [CrossRef]

57. Doglioni, C. Main differences between thrust belts. Terra Nova 1992, 4, 152-164. [CrossRef]

58. Meschis, M.; Scicchitano, G.; Roberts, G.P.; Robertson, J.; Barreca, G.; Monaco, C.; Spampinato, C.; Sahy, D.; Antonioli, F.; Mildon, Z.K.; et al. Regional Deformation and Offshore Crustal Local Faulting as Combined Processes to Explain Uplift Through Time Constrained by Investigating Differentially Uplifted Late Quaternary Paleoshorelines: The Foreland Hyblean Plateau, SE Sicily. Tectonics 2020, 39. [CrossRef]

59. Ferranti, L.; Antonioli, F.; Anzidei, M.; Monaco, C.; Stocchi, P. The timescale and spatial extent of recent vertical tectonic motions in Italy: Insights from relative sea-level changes studies. J. Virtual Explor. 2010, 36. [CrossRef]

60. Spampinato, C.R.; Scicchitano, G.; Ferranti, L.; Monaco, C. Raised Holocene paleo-shorelines along the Capo Schisò coast, Taormina: New evidence of recent co-seismic deformation in northeastern Sicily (Italy). J. Geodyn. 2012, 55, 18-31. [CrossRef]

61. Spampinato, C.R.; Braitenberg, C.; Monaco, C.; Scicchitano, G. Analysis of vertical movements in eastern Sicily and southern Calabria (Italy) through geodetic leveling data. J. Geodyn. 2013, 66, 1-12. [CrossRef]

62. Dutton, A.; Scicchitano, G.; Monaco, C.; Desmarchelier, J.M.; Antonioli, F.; Lambeck, K.; Esat, T.M.; Fifield, L.K.; McCulloch, M.T.; Mortimer, G. Uplift rates defined by U-series and 14C ages of serpulid-encrusted speleothems from submerged caves near Siracusa, Sicily (Italy). Quat. Geochronol. 2009, 4, 2-10. [CrossRef]

63. Monaco, C.; Bianca, M.; Catalano, S.; Guidi, G.; Tortorici, L. Sudden Change in the Late Quaternary Tectonic Regime in Eastern Sicily: Evidences from Geological and Geomorphological Features. Boll. Soc. Geol. Ital. 2002, 1, 901-913.

64. Antonioli, F.; Kershaw, S.; Renda, P.; Rust, D.; Belluomini, G.; Cerasoli, M.; Radtke, U.; Silenzi, S. Elevation of the last interglacial highstand in Sicily (Italy): A benchmark of coastal tectonics. Quat. Int. 2006, 145-146, 3-18. [CrossRef]

65. Spampinato, C.R.; Costa, B.; di Stefano, A.; Monaco, C.; Scicchitano, G. The contribution of tectonics to relative sea-level change during the Holocene in coastal south-eastern Sicily: New data from boreholes. Quat. Int. 2011, 232, 214-227. [CrossRef]

66. Scicchitano, G.; Antonioli, F.; Berlinghieri, E.F.C.; Dutton, A.; Monaco, C. Submerged archaeological sites along the Ionian coast of southeastern Sicily (Italy) and implications for the Holocene relative sea-level change. Quat. Res. 2008, 70, 26-39. [CrossRef]

67. Scicchitano, G.; Berlinghieri, E.F.C.; Antonioli, F.; Spampinato, C.R.; Monaco, C. Sacred Landscapes and Changing Sea Levels: New Interdisciplinary Data from the Early Neolithic to the Present in South-Eastern Sicily. In Coastal World Heritage Sites; Springer International Publishing: Geneva, Switzerland, 2017; pp. 233-253.

68. Scicchitano, G.; Spampinato, C.R.; Antonioli, F.; Anzidei, M.; Presti, V.L.; Monaco, C. Comparing Ancient Quarries in Stable and Slowly Uplifting Coastal Area Located in Eastern Sicily, Italy. Geogr. Fis. Din. Quat. 2018, 41, 81-92. [CrossRef]

69. Mulargia, F.; Achilli, V.; Broccio, F.; Baldi, P. Is a destructive earthquake imminent in southeastern Sicily? Tectonophysics 1991, 188, 399-402. [CrossRef]

70. Anzidei, M.; Lambeck, K.; Antonioli, F.; Furlani, S.; Mastronuzzi, G.; Serpelloni, E.; Vannucci, G. Coastal structure, sea-level changes and vertical motion of the land in the Mediterranean. Geol. Soc. Lond. Spéc. Publ. 2014, 388, 453-479. [CrossRef]

71. Anzidei, M.; Scicchitano, G.; Tarascio, S.; de Guidi, G.; Monaco, C.; Barreca, G.; Mazza, G.; Serpelloni, E.; Vecchio, A. Coastal Retreat and Marine Flooding Scenario for 2100: A Case Study along the Coast of Maddalena Peninsula (Southeastern Sicily). Geogr. Fis. Din. Quat. 2018, 41, 5-16. [CrossRef]

72. Vollrath, A.; Zucca, F.; Bekaert, D.; Bonforte, A.; Guglielmino, F.; Hooper, A.J.; Stramondo, S. Decomposing DInSAR Time-Series into 3-D in Combination with GPS in the Case of Low Strain Rates: An Application to the Hyblean Plateau, Sicily, Italy. Remote Sens. 2017, 9, 33. [CrossRef]

73. Scicchitano, G.; Monaco, C.; Tortorici, L. Large boulder deposits by tsunami waves along the Ionian coast of south-eastern Sicily (Italy). Mar. Geol. 2007, 238, 75-91. [CrossRef]

74. Smedile, A.; de Martini, P.; Pantosti, D.; Bellucci, L.; del Carlo, P.; Gasperini, L.; Pirrotta, C.; Polonia, A.; Boschi, E. Possible tsunami signatures from an integrated study in the Augusta Bay offshore (Eastern Sicily-Italy). Mar. Geol. 2011, 281, 1-13. [CrossRef]

75. De Martini, P.M.; Barbano, M.S.; Pantosti, D.; Smedile, A.; Pirrotta, C.; del Carlo, P.; Pinzi, S. Geological evidence for paleotsunamis along eastern Sicily (Italy): An overview. Nat. Hazards Earth Syst. Sci. 2012, 12, 2569-2580. [CrossRef]

76. De Martini, P.; Barbano, M.; Smedile, A.; Gerardi, F.; Pantosti, D.; del Carlo, P.; Pirrotta, C. A unique 4000year long geological record of multiple tsunami inundations in the Augusta Bay (eastern Sicily, Italy). Mar. Geol. 2010, 276, 42-57. [CrossRef]

77. Aucelli, P.P.C.; di Paola, G.; Incontri, P.; Rizzo, A.; Vilardo, G.; Benassai, G.; Buonocore, B.; Pappone, G. Coastal inundation risk assessment due to subsidence and sea level rise in a Mediterranean alluvial plain (Volturno coastal plain-southern Italy). Estuar. Coast. Shelf Sci. 2017, 198, 597-609. [CrossRef]

78. Bonaldo, D.; Antonioli, F.; Archetti, R.; Bezzi, A.; Correggiari, A.; Davolio, S.; de Falco, G.; Fantini, M.; Fontolan, G.; Furlani, S.; et al. Integrating multidisciplinary instruments for assessing coastal vulnerability to erosion and sea level rise: Lessons and challenges from the Adriatic Sea, Italy. J. Coast. Conserv. 2019, 23, 19-37. [CrossRef]

79. Marsico, A.; Lisco, S.; Presti, V.L.; Antonioli, F.; Amorosi, A.; Anzidei, M.; Deiana, G.; de Falco, G.; Fontana, A.; Fontolan, G.; et al. Flooding scenario for four Italian coastal plains using three relative sea level rise models. J. Maps 2017, 13, 961-967. [CrossRef] 
80. Scardino, G.; Sabatier, F.; Scicchitano, G.; Piscitelli, A.; Milella, M.; Vecchio, A.; Anzidei, M.; Mastronuzzi, G. Sea-Level Rise and Shoreline Changes Along an Open Sandy Coast: Case Study of Gulf of Taranto, Italy. Water 2020, 12, 1414. [CrossRef]

81. RING—Rete Integrata Nazionale GPS. Available online: http:/ / ring.gm.ingv.it/ (accessed on 25 April 2020).

82. Avallone, A.; Latorre, D.; Serpelloni, E.; Cavaliere, A.; Herrero, A.; Cecere, G.; D'Agostino, N.; D'Ambrosio, C.; Devoti, R.; Giuliani, R.; et al. Coseismic Displacement Waveforms for the 2016 August 24 Mw 6.0 Amatrice Earthquake (Central Italy) Carried out from High-Rate GPS Data. Ann. Geophys. 2016, 59. [CrossRef]

83. De Voti, R.; D'Agostino, N.; Serpelloni, E.; Pietrantonio, G.; Riguzzi, F.; Avallone, A.; Cavaliere, A.; Cheloni, D.; Cecere, G.; D'Ambrosio, C.; et al. A Combined Velocity Field of the Mediterranean Region. Ann. Geophys. 2017, 60, 0215. [CrossRef]

84. Herring, S.C.; Christidis, N.; Hoell, A.; Kossin, J.P.; Schreck, C.J.; Stott, P.A. Explaining Extreme Events of 2016 from a Climate Perspective. Bull. Am. Meteorol. Soc. 2018, 99, S1-S157. [CrossRef]

85. GAMIT/GLOBK. Available online: http://geoweb.mit.edu/gg/ (accessed on 6 January 2021).

86. IGS Analysis Center Coordinator (ACC). Available online: http:/ /acc.igs.org/ (accessed on 6 January 2021).

87. Maps-International GNSS Service. Available online: https:/ / www.igs.org/maps / (accessed on 6 January 2021).

88. Bos, M.S.; Fernandes, R.M.S.; Williams, S.D.P.; Bastos, L. Fast error analysis of continuous GPS observations. J. Geod. 2007, 82, 157-166. [CrossRef]

89. Goldstein, R.M.; Werner, C.L. Radar interferogram filtering for geophysical applications. Geophys. Res. Lett. 1998, 25, 4035-4038. [CrossRef]

90. Hooper, A.; Bekaert, D.; Spaans, K.; Arıkan, M. Recent advances in SAR interferometry time series analysis for measuring crustal deformation. Tectonophysics 2012, 514-517, 1-13. [CrossRef]

91. Tapete, D.; Fanti, R.; Cecchi, R.; Petrangeli, P.; Casagli, N. Satellite radar interferometry for monitoring and early-stage warning of structural instability in archaeological sites. J. Geophys. Eng. 2012, 9, S10-S25. [CrossRef]

92. Ferretti, A.; Prati, C.; Rocca, F. Analysis of Permanent Scatterers in SAR interferometry. In Proceedings of the IGARSS 2000. IEEE 2000 International Geoscience and Remote Sensing Symposium. Taking the Pulse of the Planet: The Role of Remote Sensing in Managing the Environment. Proceedings (Cat. No.00CH37120), Yokohama, Japan, 28 July-2 August 2019; IEEE: Piscataway, NJ, USA, 2002; Volume 2, pp. 761-763.

93. Berardino, P.; Fornaro, G.; Lanari, R.; Sansosti, E. A new algorithm for surface deformation monitoring based on small baseline differential SAR interferograms. IEEE Trans. Geosci. Remote Sens. 2002, 40, 2375-2383. [CrossRef]

94. Crosetto, M.; Monserrat, O.; Cuevas-González, M.; Devanthéry, N.; Crippa, B. Persistent Scatterer Interferometry: A review. ISPRS J. Photogramm. Remote Sens. 2016, 115, 78-89. [CrossRef]

95. Sentinel-Missions-Sentinel Online-Sentinel. Available online: https://sentinel.esa.int/web/sentinel/missions/sentinel-1 (accessed on 6 January 2021).

96. Geohazards TEP. Available online: https://geohazards-tep.eu/ (accessed on 6 January 2021).

97. Farr, T.G.; Rosen, P.A.; Caro, E.; Crippen, R.; Duren, R.; Hensley, S.; Kobrick, M.; Paller, M.; Rodriguez, E.; Roth, L.; et al. The Shuttle Radar Topography Mission. Rev. Geophys. 2007, 45. [CrossRef]

98. Lauknes, T.R.; Dehls, J.; Larsen, Y.; Høgda, K.; Weydahl, D. A Comparison of SBAS and PS ERS InSAR for Subsidence Monitoring in Oslo, Norway. Fringe 2005 Workshop 2006, 25, 581-587.

99. Via, G.D.; Crosetto, M.; Crippa, B. Resolving vertical and east-west horizontal motion from differential interferometric synthetic aperture radar: The L'Aquila earthquake. J. Geophys. Res. Space Phys. 2012, 117, 117. [CrossRef]

100. De Santis, V.; Caldara, M.; Torres, T.; Ortiz, J.E. Two middle Pleistocene warm stages in the terrace deposits of the Apulia region (southern Italy). Quat. Int. 2014, 332, 2-18. [CrossRef]

101. De Santis, V.; Caldara, M.; Marsico, A.; Capolongo, D.; Pennetta, L. Evolution of the Ofanto River delta from the 'Little Ice Age' to modern times: Implications of large-scale synoptic patterns. Holocene 2018, 28, 1948-1967. [CrossRef]

102. Zerbini, S.; Plag, H.-P.; Baker, T.; Becker, M.; Billiris, H.; Bürki, B.; Kahle, H.-G.; Marson, I.; Pezzoli, L.; Richter, B.; et al. Sea level in the Mediterranean: A first step towards separating crustal movements and absolute sea-level variations. Glob. Planet. Chang. 1996, 14, 1-48. [CrossRef]

103. Rete Mareografica Nazionale-Homepage. Available online: https://mareografico.it/ (accessed on 4 April 2020).

104. Van Vuuren, D.P.; Edmonds, J.; Kainuma, M.; Riahi, K.; Thomson, A.; Hibbard, K.; Hurtt, G.C.; Kram, T.; Krey, V.; Lamarque, J.-F.; et al. The representative concentration pathways: An overview. Clim. Chang. 2011, 109, 5-31. [CrossRef]

105. CORINE Land Cover-Copernicus Land Monitoring Service. Available online: http://land.copernicus.eu/ (accessed on 15 April 2020).

106. Progetto PST—Dati Lidar. Geoportale Nazionale. Available online: http://www.pcn.minambiente.it/mattm/progetto-pst-datilidar/ (accessed on 7 January 2021).

107. Global Mapper-All-in-One GIS Software. Available online: https://www.bluemarblegeo.com/products/global-mapper.php (accessed on 15 April 2020).

108. Rahmstorf, S. A Semi-Empirical Approach to Projecting Future Sea-Level Rise. Science 2007, 315, 368-370. [CrossRef]

109. Rizzo, A.; Vandelli, V.; Buhagiar, G.; Micallef, A.S.; Soldati, M. Coastal Vulnerability Assessment along the North-Eastern Sector of Gozo Island (Malta, Mediterranean Sea). Water 2020, 12, 1405. [CrossRef]

110. Ravanelli, R.; Riguzzi, F.; Anzidei, M.; Vecchio, A.; Nigro, L.; Spagnoli, F.; Crespi, M. Sea level rise scenario for 2100 A.D. for the archaeological site of Motya. Rendiconati Lince 2019, 30, 747-757. [CrossRef] 
111. Di Stefano, A.; de Pietro, R.; Monaco, C.; Zanini, A. Anthropogenic influence on coastal evolution: A case history from the Catania Gulf shoreline (eastern Sicily, Italy). Ocean. Coast. Manag. 2013, 80, 133-148. [CrossRef]

112. Lorenzo-Trueba, J.; Ashton, A.D. Rollover, drowning, and discontinuous retreat: Distinct modes of barrier response to sea-level rise arising from a simple morphodynamic model. J. Geophys. Res. Earth Surf. 2014, 119, 779-801. [CrossRef]

113. Mastronuzzi, G.; Aringoli, D.; Aucelli, P.P.C.; Baldassarre, M.A.; Bellotti, P.; Bini, M.; Biolchi, S.; Bontempi, S.; Brandolini, P.; Chelli, A.; et al. Geomorphological Map of the Italian Coast: From a Descriptive to a Morphodynamic Approach. Geogr. Fis. Din. Quat. 2017, 40, 161-195. [CrossRef]

114. De Santis, V.; Caldara, M. Evolution of an incised valley system in the southern Adriatic Sea (Apulian margin): An onshoreoffshore correlation. Geol. J. 2014, 51, 263-284. [CrossRef]

115. De Santis, V.; Caldara, M.; Pennetta, L. “Continuous” Backstepping of Holocene Coastal Barrier Systems into Incised Valleys: Insights from the Ofanto and Carapelle-Cervaro Valleys. Water 2020, 12, 1799. [CrossRef]

116. De Santis, V.; Caldara, M.; Pennetta, L. Transgressive Architecture of Coastal Barrier Systems in the Ofanto Incised Valley and Its Surrounding Shelf in Response to Stepped Sea-Level Rise. Geoscience 2020, 10, 497. [CrossRef]

117. Lionello, P.; Conte, D.; Marzo, L.; Scarascia, L. The contrasting effect of increasing mean sea level and decreasing storminess on the maximum water level during storms along the coast of the Mediterranean Sea in the mid 21st century. Glob. Planet. Chang. 2017, 151, 80-91. [CrossRef]

118. Lionello, P.; Cogo, S.; Galati, M.; Sanna, A. The Mediterranean surface wave climate inferred from future scenario simulations. Glob. Planet. Chang. 2008, 63, 152-162. [CrossRef]

119. Lin-Ye, J.; García-León, M.; Gràcia, V.; Ortego, M.I.; Lionello, P.; Conte, D.; Pérez-Gómez, B.; Sánchez-Arcilla, A. Modeling of Future Extreme Storm Surges at the NW Mediterranean Coast (Spain). Water 2020, 12, 472. [CrossRef]

120. Marcos, M.; Jordà, G.; Gomis, D.; Pérez, B. Changes in storm surges in southern Europe from a regional model under climate change scenarios. Glob. Planet. Chang. 2011, 77, 116-128. [CrossRef]

121. Bakkensen, L.A. Mediterranean Hurricanes and Associated Damage Estimates. J. Extreme Events 2017, 4, 1750008. [CrossRef]

122. Cavicchia, L.; von Storch, H.; Gualdi, S. A long-term climatology of medicanes. Clim. Dyn. 2014, 43, 1183-1195. [CrossRef]

123. Romera, R.; Gaertner, M.Á.; Sánchez, E.; Domínguez, M.; González-Alemán, J.J.; Miglietta, M.M. Climate change projections of medicanes with a large multi-model ensemble of regional climate models. Glob. Planet. Chang. 2017, 151, 134-143. [CrossRef] 